IZA DP No. 10050

Potential Parenthood and Career Progression of Men and Women: A Simultaneous Hazards Approach

Martin Biewen

Stefanie Seifert

July 2016 


\title{
Potential Parenthood and Career Progression of Men and Women: A Simultaneous Hazards Approach
}

\author{
Martin Biewen \\ University of Tübingen \\ and IZA
}

Stefanie Seifert

University of Tübingen

\section{Discussion Paper No. 10050}

July 2016

IZA

P.O. Box 7240

53072 Bonn

Germany

Phone: +49-228-3894-0

Fax: +49-228-3894-180

E-mail: iza@iza.org

Any opinions expressed here are those of the author(s) and not those of IZA. Research published in this series may include views on policy, but the institute itself takes no institutional policy positions. The IZA research network is committed to the IZA Guiding Principles of Research Integrity.

The Institute for the Study of Labor (IZA) in Bonn is a local and virtual international research center and a place of communication between science, politics and business. IZA is an independent nonprofit organization supported by Deutsche Post Foundation. The center is associated with the University of Bonn and offers a stimulating research environment through its international network, workshops and conferences, data service, project support, research visits and doctoral program. IZA engages in (i) original and internationally competitive research in all fields of labor economics, (ii) development of policy concepts, and (iii) dissemination of research results and concepts to the interested public.

IZA Discussion Papers often represent preliminary work and are circulated to encourage discussion. Citation of such a paper should account for its provisional character. A revised version may be available directly from the author. 


\title{
ABSTRACT
}

\section{Potential Parenthood and Career Progression of Men and Women: A Simultaneous Hazards Approach ${ }^{1}$}

\begin{abstract}
We analyze individual career transitions of men and women in Germany. Our particular focus is on the association of upward, downward and horizontal job changes with individual fertility. In contrast to most of the literature, we focus on potential rather than realized fertility. Based on mixed multivariate proportional hazard models with competing risks, we find a significant negative relationship between the contemporaneous probability of having a child and horizontal career transitions for women, and a positive significant association of the hazard of parenthood with upward career transitions for men. These effects persist if we apply fixed effects panel data models allowing for correlation of individual parenthood hazards with unobserved individual characteristics. Independent of their sources, our results suggest clear gender differences in the relationship between career patterns and potential fertility.
\end{abstract}

JEL Classification: J6, J7, M5

Keywords: career mobility, gender differences, hazard model

Corresponding author:

Martin Biewen

School of Business and Economics

University of Tübingen

Mohlstr. 36

72074 Tübingen

Germany

E-mail: martin.biewen@uni-tuebingen.de

\footnotetext{
${ }^{1}$ We would like to thank Daniel Hamermesh, Josef Brüderl, Astrid Kunze, Regina Riphahn, Bernd Fitzenberger, Marie Paul, Aderonke Osikominu, Joachim Grammig, Markus Niedergesäss, as well as participants of the workshop 'Perspectives on (Un-)Employment' at the IAB in Nuremberg, the $18^{\text {th }}$ IZA European Summer School in Labor Economics and the third network workshop of the DFG Priority Program 1764 for helpful comments and suggestions. This study uses the factually anonymous data of the Study 'Working and Learning in a Changing World' (ALWA). Data access was provided via a Scientific Use File supplied by the Research Data Centre (FDZ) of the German Federal Employment Agency (BA) at the Institute for Employment Research (IAB).
} 


\section{Introduction}

Gender differences in the labor market remain a hot topic in labor economics. Women generally earn less than men, their wage mobility is lower and they are underrepresented in top management positions (Blau/Kahn, 2000, Weichselbaumer/Winter-Ebmer, 2005, Manning/Swaffield, 2008, Bertrand/Hallock, 2001, Baerts et al., 2011). Some studies have found the existence of a 'glass ceiling' to women's career perspectives which excludes them from high-earnings and high-status positions (Albrecht et al., 2003, Arulampalam et al., 2007). Career progression is linked to wage growth, status and job satisfaction. Understanding differences in career transition patterns between men and women is a starting point for identifying the factors that hamper women's career progression, and may help to explain the gender gap at the upper end of the career ladder. Fertility related aspects have been considered to be a potential main driver of gender differences in the career course. A number of studies have established a relationship between career interruptions due to child rearing and slower wage growth or even wage losses (for some recent examples, see Anderson et al., 2002, Lalive/Zweimüller, 2009, Bertrand et al., 2010, Fitzenberger et al., 2013 and Drange/Rege, 2013).

While realized fertility is certainly a major candidate for explaining differences between men and women after the birth of a child, the effect of potential fertility on career transitions has received less attention. Different mechanisms may give rise to an effect of potential fertility on career transitions. The most obvious one is that employers could shy away from hiring or promoting women who have a high hazard of becoming a mother in the near future because they fear that these women might become unavailable for work because of child birth or that their productivity after child birth could suffer due to parenting duties (Lazear/Rosen, 1990). Such a mechanism follows the theory of statistical discrimination, i.e. employers might discriminate against women with a high observable pregnancy hazard, no matter whether a given woman will actually give birth to a child or not. There may also be voluntary effects of a high pregnancy hazard on career transitions, i.e. at a time at which a woman considers the possibility to become a mother to be high, she may choose not to make certain career transitions. Effects of potential fertility on career transitions may also exist for men. Employers might interpret indicators of a high hazard of imminent parenthood (e.g. marital status) as a positive signal indicating high productivity and career commitment, or such men might voluntarily make or not make certain career transitions. 
The aim of this paper is to directly investigate the relationship between the hazard of becoming a parent and the propensity for directional career movements, i.e. upward, downward and horizontal career transitions. To our best knowledge, this has not been done in this form in the literature before. We measure the career level of a person in terms of the number of subordinates directly supervised and, alternatively, by a standard occupational prestige score (in our case the Standard International Occupational Prestige Scale, SIOPS). We focus on career transitions of men and women before the birth of a first child in order to separate, as completely as possible, the aspect of potential fertility from that of realized fertility. The more general research question of our study is the comparative analysis of directional career transitions for men and women. We pursue this research question in the framework of simultaneous hazards (Lillard, 1993), i.e. the hazards of directional career movements are modeled jointly with the individual hazard of becoming a parent, whereby the parenthood hazard directly enters the hazards of directional career movements as an explanatory variable. We also take account of a large number of potential other determinants of career transitions as well as of aspects such as state dependence, duration dependence and lagged duration dependence.

This paper is structured as follows. In section 2, we review some related literature. Section 3 describes our data. In section 4, we outline our econometric framework. Section 5 presents our empirical results. Section 6 concludes.

\section{Related Literature}

There is large literature on career development of men and women. Some studies focus on promotion, some on wage growth, while others analyze job mobility covering job-to-job movements irrespective of the rank. Summarizing results on promotions is difficult, because the term promotion covers a range of different processes depending on the data used (see Gibbons/Waldman, 1999 for a theoretical overview of the term promotion and Abele et al., 2011, on career success). Many studies using survey data rely on self-reported promotions (e.g. Booth et al., 2003, Blau/DeVaro, 2007), others use employer-provided or administrative information (e.g. Pekkarinen/Vartiainen, 2006). If promotion is measured as a change in job prestige covering a job-to-job change, one needs data that have comparable scales about the hierarchical level or the job task description (see Granqvist/Persson, 2005, Pekkarinen/Vartiainen, 2006, Kunze, 2013). 
An important distinction is the one between internal and external promotions (Acosta, 2010). Internal promotions happen within the employment spell at the same employer, while external promotions refer to promotions in connection with job changes. Due to data restrictions, in this paper we will only study job-to-job movements (for more details, see below). Each transition is defined as either an upward, a downward or a horizontal movement. While upward movements can be interpreted as promotions, horizontal transitions come closer to what is labeled as job mobility in the literature. Promotions are often considered to be a main driver of wage growth (e.g. McCue, 1996). However, job mobility is theoretically and empirically also found to be closely connected to wage growth. According to the 'job shopping' theory, employees benefit from early job mobility (see e.g. Johnson, 1978, Topel/Ward 1992, Schmelzer, 2012, Bagger et al., 2014). An important implication is that, in the possible case of employer discrimination against women, reduced early job mobility may have more long-term consequences on the likelihood of upward and horizontal transitions.

Theoretically, lower career transition probabilities for women might be due to employers' behavior in processes of promotion and hiring, described by the theory of statistical discrimination (Becker, 1971, Phelps, 1972). ${ }^{2}$ According to this argument, all women face lower promotion probabilities compared to men because some women will interrupt their employment as a consequence of giving birth to a child. Following Aigner/Cain (1977) this would not necessarily result in an unwarranted discrimination of women as a group because employers need to take account of the higher separation risk of women in their hiring and promotion decisions, leading to the situation that women who do give birth later are granted a higher-than-warranted promotion probability at the expense of other women who face a promotion probability that is too low given their probability of quitting. However, in a life-cycle perspective, the women who do quit for fertility reasons later will not actually benefit from their earlier 'preferential' treatment, so that there may be a net loss for the group of women as a whole. Moreover, for many, the idea that a given individual should be 'penalized' for group characteristics or for tasks considered to be essential for the reproduction of society may seem questionable.

The central theoretical contribution in the literature modeling the consequences of higher female separation rates for job promotions is Lazear/Rosen (1990). In their model, women are assumed to have more out-of-work possibilities than men and are therefore more likely to quit in their later

\footnotetext{
${ }^{2}$ For the following, see also the discussion in Winter-Ebmer/Zweimüller (1997).
} 
employment path. Employers take this into account in their hiring and promotion decisions with the consequence that women have to be more able than men to get promoted to the next career stage. As a consequence, the final career rank and compensation is lower for women than for men, even under the assumption of an equal ability distribution for men and women.

The existing empirical literature generally shows that women are underrepresented in topmanagement and executive positions and have lower unconditional promotion rates (e.g. CobbClark, 2001, Blau/DeVaro, 2007, Smith et al., 2013, Kunze/Miller, 2014). The picture becomes less clear with respect to conditional promotion probabilities. Groot/Massen van den Brink (1996) find that women are less frequently in jobs that offer promotion possibilities, but if they are, they do not face lower promotion probabilities. The results in Blau/DeVaro (2007) suggest lower probabilities of promotion for women, but no gender differences in wage growth with or without promotions. Booth et al. (2003) present a theory and empirical evidence for the 'sticky floor' hypothesis. According to their model, women are as likely as men to get promoted but they end up at the bottom of the pay scale in the new grade. Other representative examples of literature are Hersch/Viscusi (1996), Cobb-Clark (2001), Francesconi (2001) and Johnston/Lee (2012). Results on job mobility confirm the 'job shopping' hypothesis and reveal substantial gender differences. Schmelzer (2012) finds positive wage effects of direct job mobility in the early career. According to Carrillo-Tudela et al. (2016) voluntary moves tend to be upward and connected to wage gains.

Focusing on gender differences in more detail, Granqvist/Persson (2005) show that family related factors, such as being married, have contradictory effects on men's and women's transition probabilities to higher ranked jobs. They also find negative effects of career interruptions due to child birth on women's career mobility. The result that especially variables related to family responsibilities affect men and women in a different way is also confirmed in Kunze (2013), who finds that the probability of progressing on the career ladder is reduced through children for women but not for men. On the contrary, men with one or two children are most likely to climb the career ladder. Related to these findings, there may also be effects of partnership on career progression. The hypotheses that men benefit from being in a relationship while women's career courses are negatively affected by cohabitation are often referred to as 'marriage premium' and 'marriage penalty' respectively. The theoretical arguments are based on human capital theory, but empirical evidence is mixed (Verbakel/De Graaf, 2008). Finally, Kunze/Troske (2012) exploit firm closures as a natural experiment in order to investigate gender differences in job search 
behavior. Their results suggest that gender differences in job search and mobility are related to fertility decisions and are apparent in prime-childbearing years.

As indicated above, most of the empirical literature focuses on the effects of realized but not on potential or future fertility on career paths. Exceptions are Francesconi (2002) and Adda et al. (2011), who present theoretical and empirical models of intertemporal career decisions and fertility behavior. Our more modest goal in this paper is to directly investigate the potential link between the contemporaneous probability of becoming a parent and the probabilities for different career movements. To our best knowledge, this has not been done in this form in the literature before. The study that comes closest to what we have in mind is Winter-Ebmer/Zweimüller (1997) who investigate the determinants of the current career rank of men and women and who include as an explanatory variable aggregate fertility indicators for women. Winter-Ebmer/Zweimüller (1997) do not consider transitions between ranks or potential fertility effects on men's career outcomes, and they do not explicitly model individual fertility hazards. There are also two experimental studies based on artificial job applications whose implicit research questions resemble the one considered by us. Petit (2007) presents evidence for hiring discrimination against women aged 25 applying for high-skilled administrative jobs but no discrimination of women among single and childless applicants aged 37. Baert (2014) finds evidence for discrimination of young heterosexual women (compared to homosexual women) when applying for job vacancies. Compared to the cited articles, our goal is to explicitly model the relationship between the individual hazard of becoming a mother or a father and the hazards for different career movements in a joint way using the simultaneous hazards approach introduced by Lillard (1993). ${ }^{3}$ In view of the literature, our hypothesis is that the probability of upward and horizontal career transitions is negatively related to the parenthood hazard for women, while we conjecture that high contemporaneous parenthood hazards might constitute a positive career signal for men. We further expect (other) family related variables to differently affect men's and women's career transitions.

\footnotetext{
${ }^{3}$ Applications of this approach are, for example, Lillard/Waite (1993), and Aassve et al. (2006) who model the hazard of conception along with the hazard of marital disruption for married couples.
} 


\section{Data}

For our analysis, we need data covering personal employment, partnership and fertility information in one data set. For this purpose, we use the survey 'Working and Learning in a Changing World' (ALWA) provided by the Institute for Employment Research (IAB) at the German Federal Employment Agency which contains life-cycle information of more than 10,400 individuals (Kleinert et al., 2011). Besides information on schooling and training, the data set includes detailed monthly information on labor market behavior as well as on processes of family formation and regional mobility. In addition, we merged variables on aggregate and regional unemployment, employment and fertility available from the statistical offices to our data set. The employment history is reported per episode, with a new episode defined by a change of employer, a change in the task performed or by an employment interruption such as unemployment, parental leave or military service. As a preparatory step, we first generated a complete employment history for every individual for which we adjusted parallel spells by defining main and secondary employment resolving cases of overlapping schooling or training spells. In our final data set, every month from age fifteen onwards is uniquely identified as either an employment or a non-employment spell. In certain cases, e.g. if an employment spell was followed by a short interruptive spell of search unemployment, we extended the first spell to also include the short intermediate spell. We did this in order to avoid an employment spell to be classified as censored, although from a substantive point of view, there was a career transition to a subsequent employment spell. If an employment spell was artificially extended, we controlled for this and the exact reason why it was extended in our hazard model estimates. Employment spells that were followed by non-employment spells were treated as being censored.

For every employment episode we have information on the occupational task performed by a person as well as on individual and establishment characteristics. In order to classify job changes as upward, downward or horizontal transitions, we defined the career level during a given job spell by the number of subordinates supervised by the person in question. A change in this number by three or more people defines an upward or a downward movement. In the case of no change or a change by no more than two subordinates, an employment transition was classified as a 'horizontal' career movement. We experimented with different definitions of upward/downward movements but found this definition to be a good compromise between the substantive concept of an upward/downward transition and the resulting number of transitions. 
As an alternative indicator of the career level, we used the Standard International Occupational Prestige Scale (SIOPS) which was designed for coding internationally comparable measures of occupational status based on the International Standard Classification of Occupation 1988 (ISCO88). The SIOPS scale, originally developed by Treiman (1977), ranges from 0 to 100. Its construction is based on results from national surveys on the rating of different occupations in terms of rank (for a detailed description of the coding procedures see Ganzeboom/Treiman, 1996). We define upward and downward transitions as any upward or downward change in the SIOPS score.

We restrict our sample to the birth cohorts 1956 to 1988 and to individuals living in West Germany or East Germany after 1990. We only consider individuals (men and women) before they become parents for the first time. We do this in order to exclusively focus on the effects of potential rather than of realized fertility. Moreover, in this way we avoid difficult problems of sample selection as the group of individuals who continue to work after first birth is likely to be highly selective (especially for women). Our final sample includes 2,883 women and 2,734 men. We observe 2.2 career spells per individual on average. Table 1 shows descriptive statistics on the number and duration of employment spells. Descriptive statistics of all relevant variables are summarized in table 7 in the appendix.

- Table 1 about here -

For the 2,883 (2,734) women (men) in our sample we observe 5,482 $(6,194)$ job spells. 2,355 $(3,041)$ of those end with a transition to a subsequent job episode that can be characterized as an upward, downward or horizontal transition as measured by a change in the number of subordinates (see top panel of table 1). Censored spells are followed by an episode without employment which could be unemployment, educational spells or other interruptions. Censored spells are on average three times as long as spells ending in an upward or horizontal transition and twice as long as spells leading to a downward transition. This pattern is observed for both women and men. It suggests that individuals who 'climb the career ladder' do so very quickly, while those who plan to exit the labor market or to step down on the career ladder remain longer in their current position. The numbers for changes in the SIOPS shown in the lower panel of table 1 are slightly different due to differential missing values and due to the different definition of transitions. In order to figure out whether these transitions are driven by a pattern of duration dependence, or whether 
and which other factors influence the duration or exit route of a job spell, further covariates have to be considered in a multivariate setup.

\section{Econometric Framework}

\section{Mixed Multivariate Proportional Hazard Model}

Our goal is to model the pregnancy hazard - or more generally the parenthood hazard ${ }^{4}$ - simultaneously with the hazards of making an upward, downward or horizontal career transition. For this purpose, we estimate a multivariate proportional hazard model with competing risks, in which the parenthood hazard enters as an explanatory variable in the hazards for making one of the three career transitions (see van den Berg, 2001, and Lillard, 1993).

Our simultaneous model looks as follows:

$$
\begin{aligned}
\ln h^{p}\left(t \mid x_{i t}, z_{i t}\right) & =x_{i t} \gamma_{x}^{p}+z_{i t} \gamma_{z}^{p} \\
\ln h^{u}\left(t \mid x_{i t}, v_{i}\right) & =x_{i t} \beta^{u}+\delta^{u} \ln h^{p}\left(t \mid x_{i t}, z_{i t}\right)+v_{i}^{u} \\
\ln h^{d}\left(t \mid x_{i t}, v_{i}\right) & =x_{i t} \beta^{d}+\delta^{d} \ln h^{p}\left(t \mid x_{i t}, z_{i t}\right)+v_{i}^{d} \\
\ln h^{h}\left(t \mid x_{i t}, v_{i}\right) & =x_{i t} \beta^{h}+\delta^{h} \ln h^{p}\left(t \mid x_{i t}, z_{i t}\right)+v_{i}^{h} .
\end{aligned}
$$

In this model, $h^{p}\left(t \mid x_{i t}, z_{i t}\right)$ denotes individual $i$ 's hazard of starting parenthood at time $t$ given characteristics $x_{i t}$ and $z_{i t}$. The variables $x_{i t}$ and $z_{i t}$ used to predict this hazard are assumed to be observable information available in a CV in order to mimic employers' predictions of how likely it is for a person with characteristics $x_{i t}$ and $z_{i t}$ to start parenthood at time $t$, where $z_{i t}$ is assumed to contain variables that do not appear in the hazards for the different career transitions. The terms $h^{u}\left(t \mid x_{i t}, v_{i}\right), h^{d}\left(t \mid x_{i t}, v_{i}\right), h^{h}\left(t \mid x_{i t}, v_{i}\right)$ denote the hazards of making an upward, downward or horizontal career transition at time $t$ given explanatory variables $x_{i t}$ and conditional on unobserved heterogeneity $v_{i}=\left(v_{i}^{u}, v_{i}^{d}, v_{i}^{h}\right)$.

As explanatory variables $x_{i t}$ we consider socioeconomic information (educational and employment history, age, experience, partner information, employer characteristics) as well as regional information based on the person's residential history (see below for more details). We also consider

\footnotetext{
${ }^{4}$ We define the observed time of birth of a child minus nine months as the beginning of parenthood. In this way we also cover the time of pregnancy, which seems to make most sense especially in the case of women.
} 
the dependence of career transitions on the time already spent at the given or at previous career levels (duration dependence and lagged duration dependence). In addition, the contemporaneous parenthood hazard $h^{p}\left(t \mid x_{i t}, z_{i t}\right)$ enters as an explanatory variable in each of the three directional career hazards. The vector $v_{i}=\left(v_{i}^{u}, v_{i}^{d}, v_{i}^{h}\right)$ denotes individual-specific terms that capture potentially correlated unobserved characteristics $v_{i}^{u}, v_{i}^{d}$ and $v_{i}^{h}$ influencing certain career movements. Such unobserved heterogeneity may arise if different types of persons with time-constant preferences for career transitions exist, i.e. individuals who are generally more or less mobile, or more upwards or downwards mobile conditional on observed characteristics $x_{i t}$. Given the structure of the model, we include instrumental variables $z_{i t}$ in the equation for the pregnancy hazard, which are, in our empirical implementation, the birthrate by year and federal state as well as the amount of potential child allowance in a given year. The full list of explanatory variables used in the four hazard equations is given in table 2.

- Table 2 about here -

For the three career hazards we assume a competing risks structure, i.e. the probability of making a particular career transition at time $t$ is computed as the product of the probability of making this transition at $t$ and the probability of not making any of the other two career transitions until $t$. The resulting likelihood contribution for month $t$ of individual $i$ is given by

$$
\begin{aligned}
\mathcal{L}\left(t \mid x_{i t}, v_{i}\right)= & h^{u}\left(t \mid x_{i t}, v_{i}^{u}\right)^{u p_{i t}} \times h^{d}\left(t \mid x_{i t}, v_{i}^{d}\right)^{\text {down }_{i t}} \times h^{h}\left(t \mid x_{i t}, v_{i}^{h}\right)^{h o r i z_{i t}} \times h^{p}\left(t \mid x_{i t}, z_{i t}\right)^{p_{i t}} \\
& \times \exp \left\{-\sum_{j=u, d, h} \int_{t-1}^{t} h^{j}\left(t \mid x_{i t}, v_{i}^{j}\right)\right\} \times \exp \left\{-\int_{t-1}^{t} h^{p}\left(t \mid x_{i t}, z_{i t}\right)\right\}
\end{aligned}
$$

where $u p_{i t}$, down $n_{i t}$, horiz $z_{i t}$ and $p_{i t}$ are dummies indicating an upward, downward, horizontal or parenthood transition at the end of month $t$. In order to integrate out the unobserved effect $v=\left(v^{u}, v^{d}, v^{h}\right)$ we assume a discrete mass point distribution $A^{*}(v)$ with two mass points leading to the likelihood conditional on observed information

$$
\mathcal{L}\left(t \mid x_{i t}\right)=\int_{v} \mathcal{L}\left(t \mid x_{i t}, v\right) d A^{*}(v) .
$$

\section{Fixed Effects SUR Model}

We also consider a fixed effects panel data model in which we jointly model the monthly probabilities of upward, downward and horizontal career transitions along with the monthly probability 
of starting parenthood. As in the mixed multivariate proportional hazard model, this addresses the aspect that the individual hazard of becoming a mother or father may be correlated with unobserved individual characteristics (such as time-constant preferences).

The resulting model is given by

$$
\begin{aligned}
p_{i t} & =x_{i t} \gamma_{x}^{p}+z_{i t} \gamma_{z}^{p}+\epsilon_{i t}^{p}, \quad \hat{h}_{i t}^{p}=x_{i t} \gamma_{x}^{p}+z_{i t} \gamma_{z}^{p} \\
u p_{i t} & =x_{i t} \beta^{u}+\delta^{u} \hat{h}_{i t}^{p}+\epsilon_{i t}^{u}+c_{i}^{u} \\
\text { down }_{i t} & =x_{i t} \beta^{d}+\delta^{d} \hat{h}_{i t}^{p}+\epsilon_{i t}^{d}+c_{i}^{d} \\
\text { hori }_{i t} & =x_{i t} \beta^{h}+\delta^{h} \hat{h}_{i t}^{p}+\epsilon_{i t}^{h}+c_{i}^{h},
\end{aligned}
$$

where $c_{i}^{e}(e=u, d, h)$ denote time-constant person-specific fixed effects for the different career directions and $\epsilon_{i t}^{e}(e=p, u, d, h)$ are idiosyncratic error terms.

Demeaning the explanatory variables in the career equations leads to the following system of equations which we estimate by efficient NLSUR (e.g. Greene, 2012):

$$
\begin{aligned}
& p_{i t}=x_{i t} \gamma_{x}^{p}+z_{i t} \gamma_{z}^{p}+\epsilon_{i t}^{p} \\
& \left(u p_{i t}-\overline{u p}_{i}\right)=\left(x_{i t}-\bar{x}_{i}\right) \beta^{u}+\delta^{u}\left(\hat{h_{i t}^{p}}-\overline{\hat{h}_{i}^{p}}\right)+\left(\epsilon_{i t}^{u}-\overline{\epsilon_{i}^{u}}\right) \\
& \left(\text { down }_{i t}-\overline{\text { down }}_{i}\right)=\left(x_{i t}-\bar{x}_{i}\right) \beta^{d}+\delta^{d}\left(\hat{h_{i t}^{p}}-\overline{\hat{h}_{i}^{p}}\right)+\left(\epsilon_{i t}^{d}-\overline{\epsilon_{i}^{d}}\right) \\
& \left(h_{o r i} z_{i t}-\overline{h o r i z}_{i}\right)=\left(x_{i t}-\bar{x}_{i}\right) \beta^{h}+\delta^{h}\left(\hat{h_{i t}^{p}}-\overline{\hat{h}_{i}^{p}}\right)+\left(\epsilon_{i t}^{h}-\overline{\epsilon_{i}^{h}}\right) \text {. }
\end{aligned}
$$

The model has the straightforward interpretation that we measure, within individuals' career trajectories, to what extent the probability of making a particular career transition is above or below its individual-specific average at times at which the individual's pregnancy hazard is above or below its individual-specific average. As a variation, we consider spell fixed effects, i.e. $c_{i}^{e}(e=u, d, h)$ are assumed to be constant within career spells, but may be different across career spells. We compute standard errors clustered at the level of the individual throughout all our estimations.

\section{Empirical Results}

Figure 1 presents the unconditional hazard rates for the different exit routes separately for men and women for the case in which we measure career status by the number of subordinates. The 
graphs generally suggest lower career mobility for women than for men, especially with respect to upward and horizontal movements.

\section{— Figure 1 about here -}

In order to identify the influence of certain regressors on the hazard rates of the different career directions, we estimate the models described in the previous section. Our main regressor of interest is the contemporaneous probability of parenthood, which is modeled as a conditional hazard rate. Figure 2 illustrates the distribution of predicted parenthood hazards as estimated by (7). For both men and women, the distribution of predicted parenthood hazards has two peaks which turn out to be the masses of married and unmarried individuals.

\section{— Figure 2 about here -}

Table 3 reports the determinants of the parenthood hazard as estimated in (1) for the case in which we measure career status by the number of subordinates. ${ }^{5}$ We find a nonlinear relationship between the parenthood hazard and age. For women, no births are reported in our data for individuals older than 45 years, thus we group the last two age categories in order to avoid perfect predictions. The results also suggest a concave experience pattern in the probability of parenthood as well as significant and strong effects of religion, the regional birth rate, being married and living in East Germany.

\section{- Table 3 about here -}

While the effects on the timing of first birth are relatively similar in the male and female subsample, gender differences are more prevalent in the estimated coefficients of the career hazard equations. We find that many of the effects on the three transition directions are different between men and women, both in significance and magnitude. Especially variables related to fertility turn out to interact with the career development in different ways. The results for the mixed multivariate proportional hazard model are shown in table 4.

\footnotetext{
${ }^{5}$ The results from the estimation based on changes in the occupational rank as described by the SIOPS were almost identical.
} 
For our main variable of interest, the results suggest that the parenthood hazard is significantly negatively related to women's horizontal job mobility. Given the log-log specification, a one percent higher parenthood hazard is associated with a .18 percent lower hazard for horizontal career transitions. For upward transitions, we find a negative but statistically insignificant relationship. For downward transitions, the association is small and positive but also statistically insignificant. For men, the results suggest a significant positive association of the parenthood hazard with upward transitions and insignificant effects for downward and horizontal transitions. The results imply that for men, a one percent higher parenthood hazard translates into a .20 percent higher hazard for climbing up the career ladder. These results are consistent with the hypothesis that for employers, anticipated parental responsibilities of a male employee may be a positive signal of reliability and stability, fostering job transitions to higher hierarchical levels. For women, the results suggest that horizontal (but not upward) mobility is hampered by a high probability of becoming a mother in the near future.

Table 4 also shows other interesting effects. To identify the effect of cohabitation we use individuals with no partner as the reference category compared to those with partners with high or low education. The education variable is supposed to capture differences in human capital (Verbakel/De Graaf, 2008). It turns out that cohabiting with a partner with low education decreases women's propensity to change to a job with a higher level of personnel responsibility, while it makes an upward transition for men more likely. For women, the same relationship is observed for horizontal transitions, but of a smaller magnitude. This asymmetry may reflect that men are often unwilling to be 'overtaken' by their female partners. By contrast, cohabiting with a highly educated partner increases the likelihood of upward career transitions for men and women. These cases may reflect career competition within relationships or support through the high level of human capital of the partner. We find no age effects when it comes to upward or downward career movements after we control for the parenthood hazard. A stable result across all equations and both genders is the significant effect of the mobility indicator (i.e. number of residential changes in the last 24 months). This effect is likely to pick up the potential link between career changes and residential mobility.

The likelihood of making an upward, downward or horizontal transition strongly depends on the current position in the career hierarchy. We find strong effects of negative state dependence 
(LEVEL) for upward and horizontal transitions for both men and women. This mostly reflects the fact that with increasing personnel responsibility further improvements become harder because the number of vacancies at higher hierarchical levels is smaller. For men, we additionally find a positive state dependence at higher ranks for downward transitions. As to the effect of duration dependence (CAR), we observe no strong duration dependence effects for upward or downward transitions for women, suggesting that no 'career automatism' exists. If anything, we observe negative duration dependence for horizontal transitions. For men, the negative duration dependence can be observed for all transition types. This indicates that career mobility is stronger in the early phase of an employment spell, whereas individuals tend to become less mobile with rising tenure. We also consider effects of lagged duration dependence (LDsub, LDnosub). We do so separately for past spells with and without personnel responsibility. Having already worked in a job with subordinates is weakly positively related to the hazard of upward transitions for women. This suggests dynamic effects in career paths implying that earlier disadvantages (such as the negative parenthood effect for women's horizontal transitions) have additional long-term consequences. For men, we find a generally negative effect of past spell lengths with downward movements, irrespective of whether they were with or without subordinates.

As to the effect of educational qualifications on career transitions, our results suggest that the likelihood of making horizontal transitions increases with the degree of formal education for women. For men, we find that the likelihood of upward transitions rises with a higher educational level. For horizontal movements we especially find a positive association with tertiary education. Our results for the self-reported indicators of maths skills and verbal abilities conform to prior expectations: individuals with higher ability are significantly more likely to climb up the career ladder, while we find no effects of our ability indicators on downward and horizontal transitions. ${ }^{6}$ Interestingly, high verbal competence scores are much more important for upward transitions of women than for those of men. This directly corresponds to the well-known feature of Lazear/Rosen (1990)'s model that women have to pass a higher ability threshold than men in order to proceed to a higher career level. We observe a positive association of the number of past jobs with downward and horizontal job changes for men, suggesting a general pattern of mobility or immobility respectively. However, for women, the number of past jobs is negatively related to downward and horizontal job movements, which may be interpreted as a career pattern in which mobility tends to decrease over time. For both men and women, we do not estimate a

\footnotetext{
${ }^{6}$ Note that in our data, high values of the competence score mean low ability.
} 
separate effect of the number of past jobs on the likelihood of upward movements. This may be interpreted as evidence against the hypothesis that 'job shopping' has positive effects on further career progression. The effects for the other covariates shown in table 4 are mostly in line with expectations and are therefore not discussed here.

Table 4 also shows our results for the two mass points of the unobserved heterogeneity term $v .^{7}$ Our results suggest two types of women, one with $v^{1}=\left(v^{u}, v^{d}, v^{h}\right)=(-6.335,-6.978,-5.838)$ and one with $v^{2}=(-4.990,-5.221,-4.817)$. The proportion of type 1 in the population of women is $p=0.891$, that of type 2 is $(1-p)=0.109$. Type 2 is uniformly more mobile than type 1 . There are no differential effects of unobserved heterogeneity with respect to the different mobility directions. This is remarkable as, in principle, it would be possible that one of the types is more upward but less downward mobile than the other type. The pattern of unobserved heterogeneity is slightly different for men. Here, type 1 with $v^{1}=(-4.785,-6.871,-4.843)$ is more mobile than type 2 with $v^{2}=(-6.514,-9.139,-4.431)$ except for the slightly stronger tendency of not changing to lower personnel responsibility.

\section{- Table 5 about here -}

Table 5 shows the mixed multivariate proportional hazard estimates for the specification with changes in the occupational rank described by the SIOPS. With very few exceptions, the results are remarkably consistent with the ones obtained in the model with the number of subordinates as the dependent variable. This is particularly true for the estimated association of the parenthood hazard with the likelihood for different career transitions. As in the specification with the number of subordinates, we find a statistically significant negative association of the likelihood of becoming a parent with horizontal job movements for women, and a significantly positive association with upward mobility for men. Note that the effects of the parenthood hazard on job transitions from this specification and from all other specifications estimated by us are reproduced in table 6 .

\section{— Table 6 about here -}

\footnotetext{
${ }^{7}$ We also experimented with more than two mass points but found it very hard to achieve convergence of our estimation routine. This is not surprising given the complexity of the estimated model and the large number of estimated parameters. In the cases in which we achieved convergence, there were usually two mass points which looked very similar indicating that we cannot identify more than two sufficiently different latent groups in our data.
} 
We now turn to the fixed effects approach to estimating our system of hazard equations. The advantage of the fixed effects model (7) to (10) is that the parenthood hazard (and all other explanatory variables) may be arbitrarily correlated with unobserved time-constant (or, alternatively, spell-constant) determinants of individual career transitions. In this way, we difference out unobserved person-specific characteristics such as time-constant personal preferences or personal circumstances, which may also influence career transitions. Results for these estimations are given in table 8 in the appendix.

The most important result in these estimations is that our main findings concerning the effect of the parenthood hazard on career transitions also survive in a fixed effects setting. The estimates for women based on the number of subordinates suggest that the monthly probability of a horizontal job transition is significantly negatively related to the monthly probability of starting parenthood. More concretely, if the probability of becoming a mother is increased by one percentage point, the probability of a horizontal job transition is reduced by .24 percentage points. It is not significantly related to upward or downward transitions. For men, the parenthood hazard is significantly positively related to upward transitions but unrelated to downward or horizontal transitions. In particular, the probability of an upward transition is increased by about 08 percentage points if the parenthood hazard is raised by one percentage point. Note that many of the other estimated effects in table 8 are relatively insignificant, which is a typical result for within-estimates of explanatory variables with limited temporal variation.

The results for the case in which we allow the fixed effects to vary over career spells are given in table 9 in the appendix. The main effects are reproduced in table 6 . In this specification, there may be person-specific effects that are constant within career spells, but different across career spells. Again, the results confirm our previous findings about the relationship between the parenthood hazard and career transitions. As before, a higher parenthood hazard for women is significantly related to lower horizontal career mobility. Moreover, the (smaller) negative relationship between the parenthood hazard and upward transitions, which appeared in similar form in the mixed multivariate proportional hazard model and in the model with person-specific fixed effects, turns significant in the model with spell-specific fixed effects. For men, the results confirm the finding of the mixed multivariate proportional hazard model and the model with person-specific fixed effects that a higher parenthood hazard is positively associated with a higher likelihood of upward transitions. 
Table 6 also shows the fixed effects results based on changes in the SIOPS as the dependent variable (the full results for these specifications are available upon request). Both in the person fixed effects and in the spell fixed effects case, we obtain a negative association of the parenthood hazard with horizontal transitions for women which is of the same magnitude as in the specification with changes in the number of subordinates as the dependent variable. Moreover, in the SIOPS fixed effects case the (much smaller) negative effect of the parenthood hazard on women's upward transitions becomes statistically significant. For men, the fixed effects results for the SIOPS case look more mixed and are much less significant.

Taken together, the results in table 6 suggest a robust and statistically significant positive relationship between the probability of parenthood and horizontal job changes for women. In some specifications, we also observe a smaller negative relationship between the likelihood of becoming a mother and upward mobility. For men, the results suggest a significant positive relationship between the parenthood hazard and upward mobility which is robust across almost all specifications.

\section{Conclusion}

This paper analyzes career progression patterns of childless men and women in Germany. The descriptive analysis of career transition hazards confirms previous findings in the literature that women generally exhibit lower career mobility than men. In order to investigate the determinants of individual career transitions in more detail, we estimated a mixed multivariate proportional hazard model with competing risks for upward, downward and horizontal job transitions while simultaneously modeling the hazard of first births and its effect on career transitions. As an alternative specification, we considered a fixed effects approach. Our results suggest that a high contemporaneous probability of becoming a parent significantly lowers horizontal but not upward or downward career mobility for women. In some specifications we also find a significant but smaller negative association with female upward career mobility. For men, we find that a higher contemporaneous probability of becoming a parent increases the likelihood of upward but not of downward or horizontal career transitions. These results persist if we allow for a correlation of parenthood hazards with unobserved individual characteristics such as time- or spell-constant personal preferences in a fixed effects model. 
We believe that our findings contribute to the literature on the relationship between fertility hazards and career transition patterns. To the extent that our estimations net out unobserved differences in preferences, our results are consistent with the hypothesis that women's career mobility is to a certain extent hampered by the hazard of becoming a mother while that of men is increased by a high probability of becoming a father. We would certainly not go so far as to interpret these findings as clear evidence for employer discrimination. Such an interpretation would rest, among other things, on the assumption that career preferences are time- or spellconstant, which would be hard to defend. Incorporating time-varying preferences into an empirical analysis seems extremely hard but might be an interesting challenge for future research. On the other hand, in the case of substantial employer discrimination, we would probably expect the association of fertility hazards with female horizontal or upward job mobility to be more pronounced. Independent of the sources of the effects measured by us, we obtain the important result that there are clear gender differences in the relationship between potential fertility and individual career patterns. This is a highly relevant point for labor market policy. Regardless of whether employer discrimination exists, in the labor market studied by us even prospective fertility is not gender neutral with respect to further career progression. 


\section{References}

Aassve, A., S. Burgess, C. Propper, and M. Dickson (2006): Employment, family union and childbearing decisions in Great Britain, Journal of the Royal Statistical Society: Series A (Statistics in Society), 169, 781-804.

Abele, A. E., D. Spurk, and J. Volmer (2011): The construct of career success: measurement issues and an empirical example, Zeitschrift für Arbeitsmarktforschung, 43, 195-206.

Acosta, P. (2010): Promotion dynamics the Peter Principle: Incumbents vs. external hires, Labour Economics, 17, 975-986.

Adda, J., C. Dustmann and K. Stevens (2011): The Career Costs of Children, IZA Discussion Paper, No. 6201, Institute for the Study of Labor, Bonn.

Aigner, D. J., and G.G. Cain (1977): Statistical Theories of Discrimination in Labor Markets, Industrial and Labor Relations Review, 30, 175-87.

Albrecht, J., A. Björklund, and S. Vroman (2003): Is There a Glass Ceiling in Sweden?, Journal of Labor Economics, 21, 145-77.

Anderson, D. J., M. Binder, and K. Krause (2002): The Motherhood Wage Penalty: Which Mothers Pay It and Why?, American Economic Review, 92, 354-358.

Arulampalam, W., A. Booth and M. Bryan. (2007): Is There a Glass Ceiling over Europe? Exploring the Gender Pay Gap Across the Wage Distribution, Industrial and Labor Relations Review, 60, 163-186.

Baert, S. (2014): Career lesbians. Getting Hired for Not Having Kids?, Industrial Relations Journal, 45, 543-561.

Baerts, A., N. Deschacht, and M.A. Guerry (2011): The Role of the Partner in Promotions to Top Positions in Belgium, European Sociological Review, 27,654-668.

Bagger, J., F. Fontaine, F. Postel-Vinay, and J. M. Robin (2014): Tenure, Experience, Human Capital, and Wages: A Tractable Equilibrium Search Model of Wage Dynamics, American Economic Review, 104, 1551-1596. 
Becker, G. S. (1957): The economics of discrimination, University of Chicago Press, Chicago.

Bertrand, M., C. Goldin, and L. F. Katz (2010): Dynamics of the Gender Gap for Young Professionals in the Financial and Corporate Sectors, American Economic Journal: Applied Economics, 228-255.

Bertrand, M., and K. F. Hallock (2001): The Gender Gap in Top Corporate Jobs, Industrial and Labor Relations Review, 55, 3-21.

Blau, F.D., and J. DeVaro (2007): New Evidence on Gender Differences in Promotion Rates: An Empirical Analysis of a Sample of New Hires, Industrial Relations: A Journal of Economy and Society, 46, 511-550.

Blau, F.D., and L.M. Kahn (2000): Gender Differences in Pay, Journal of Economic Perspectives, 14, 75-99.

Booth, A. L., M. Francesconi, and J. Frank (2003): A sticky floors model of promotion, pay, and gender, European Economic Review, 47, 295-322.

Carrillo-Tudela, C., B. Hobijn, P. She, and L. Visschers (2016): The Extent and Cyclicality of Career Changes: Evidence for the U.K., forthcoming in the European Economic Review.

Cobb-Clark, Deborah A. (2001): Getting ahead: The determinants of and payoffs to internal promotion for young U.S. men and women, Research in Labor Economics, 20, 339-372.

Drange, N., and M. Rege (2013): Trapped at home: The effect of mothers' temporary labor market exits on their subsequent work career, Labour Economics, 24, 125-136.

Fitzenberger, B., K. Sommerfeld, and S. Steffes (2013): Causal effects on employment after first birth - A dynamic treatment approach, Labour Economics, 25, 49-62.

Francesconi, M. (2001): Determinants and consequences of promotions in Britain, Oxford Bulletin of Economics and Statistics, 63, 279-310.

Francesconi, M. (2002): A Joint Dynamic Model of Fertility and Work of Married Women, Journal of Labor Economics, 20, 336-380.

Ganzeboom, H. B., and D. J. Treiman (1996): Internationally comparable measures of occu- 
pational status for the 1988 International Standard Classification of Occupations, Social science research, 25, 201-239.

Gibbons, R., and M. Waldman (1999): A Theory of Wage and Promotion Dynamics inside Firms, Quarterly Journal of Economics, 114, 1321-1358.

Granqvist, L., and H. Persson (2005): Career mobility and gender on the Swedish labour market, International Journal of Manpower, 26, 116-139.

Greene, W. (2012): Econometric Analysis, 7th ed., Upper Saddle River, NJ: Prentice Hall.

Groot, W., and H. Maassen van den Brink (1996): Glass ceilings or dead ends: Job promotion of men and women compared, Economics Letters, 53, 221-226.

Hersch, J., and W. Viscusi (1996): Gender Differences in Promotions and Wages, Industrial Relations: A Journal of Economy and Society, 35, 461-472.

Johnson, W.R. (1978): A theory of job shopping, The Quarterly Journal of Economics, 92, 261-278.

Johnston, D.W., and W.S. Lee (2012): Climbing the Job Ladder: New Evidence of Gender Inequity, Industrial Relations: A Journal of Economy and Society, 51(1), 129-151.

Kleinert, C., B. Matthes, M. Antoni, K. Drasch, M. Ruland, and A. Trahms (2011): ALWA - new life course data for Germany, Journal of Applied Social Science Studies (Schmoller's Jahrbuch), $131,625-634$.

Kunze, A. (2013): Gender differences in career progression: Does the effect of children capture low work effort?, Paper presented at the Conference of the German Economic Association Annual Conference 2013 (Duesseldorf).

Kunze, A., and A. R. Miller (2014): Women helping women? Evidence from private sector data on workplace hierarchies, National Bureau of Economic Research Working Paper, No. 20761.

Kunze, A., and K. R. Troske (2012): Life-cycle patterns in male/female differences in job search, Labour Economics, 19, 176-185.

Lalive, R., and J. Zweimüller (2009): How does parental leave affect fertility and return to work? 
Evidence from two natural experiments, Quarterly Journal of Economics, 124, 1363-1402.

Lazear, E. P., and S. Rosen (1990): Male-Female Wage Differentials in Job Ladders, Journal of Labor Economics, 8, 106-123.

Lillard, L. A. (1993): Simultaneous equations for hazards: Marriage duration and fertility timing, Journal of Econometrics, 56, 189-217.

Lillard, L. A., and L. J. Waite (1993): A Joint Model of Marital Childbearing and Marital Disruption, Demography, 30, 653-681.

Manning, A. and J. Swaffield (2008): The Gender Gap in Early-Career Wage Growth, Economic Journal, 118, 983-1024.

McCue, K. (1996): Promotions and Wage Growth, Journal of Labor Economics, 175-209.

Pekkarinen, T., and J. Vartiainen (2006): Gender Differences in Promotion on a Job Ladder: Evidence from Finnish Metalworkers, Industrial and Labor Relations Review, 59, 285-301.

Petit, P. (2007): The effects of age and family constraints on gender hiring discrimination: A field experiment in the French financial sector, Labour Economics, 14, 371-391.

Phelps, E. S. (1972): The Statistical Theory of Racism and Sexism, The American Economic Review, 62, 659-661.

Schmelzer, P. (2012): The Consequences of Job Mobility for Future Earnings in Early Working Life in Germany - Placing Indirect and Direct Job Mobility into Institutional Context, European Sociological Review, 28, 82-95.

Smith, N., V. Smith, and M. Verner (2013): Why Are So Few Females Promoted into CEO and Vice President Positions? Danish Empirical Evidence, 1997-2007, Industrial and Labor Relations Review, 66, 380-408.

Topel, R.H., and M.P. Ward (1992): Job Mobility and the Careers of Young Men, Quarterly Journal of Economics, 107, 439-479.

Treiman, D.J. (1977): Occupational Prestige in Comparative Perspective, Academic Press, NewYork. 
Van den Berg, G.J. (2001): Duration Models: Specification, Identification and Multiple Durations, in: J.J. Heckman and E.E. Leamer (eds.), Handbook of Econometrics, Vol. 5, chapter 55, 3381-3460.

Verbakel, E., and P. M. De Graaf (2008): Resources of the Partner: Support or Restriction in the Occupational Career? Developments in the Netherlands Between 1940 and 2003, European Sociological Review, 24, 81-95.

Weichselbaumer, D., and R. Winter-Ebmer (2005): A Meta-Analysis on the International Gender Wage Gap, Journal of Economic Surveys, 19, 479-511.

Winter-Ebmer, R., and J. Zweimüller (1997): Unequal Assignment and Unequal Promotion in Job Ladders, Journal of Labor Economics, 43-71. 


\section{Graphs}

Figure 1 - Unconditional Hazard Rate (Number of Subordinates)
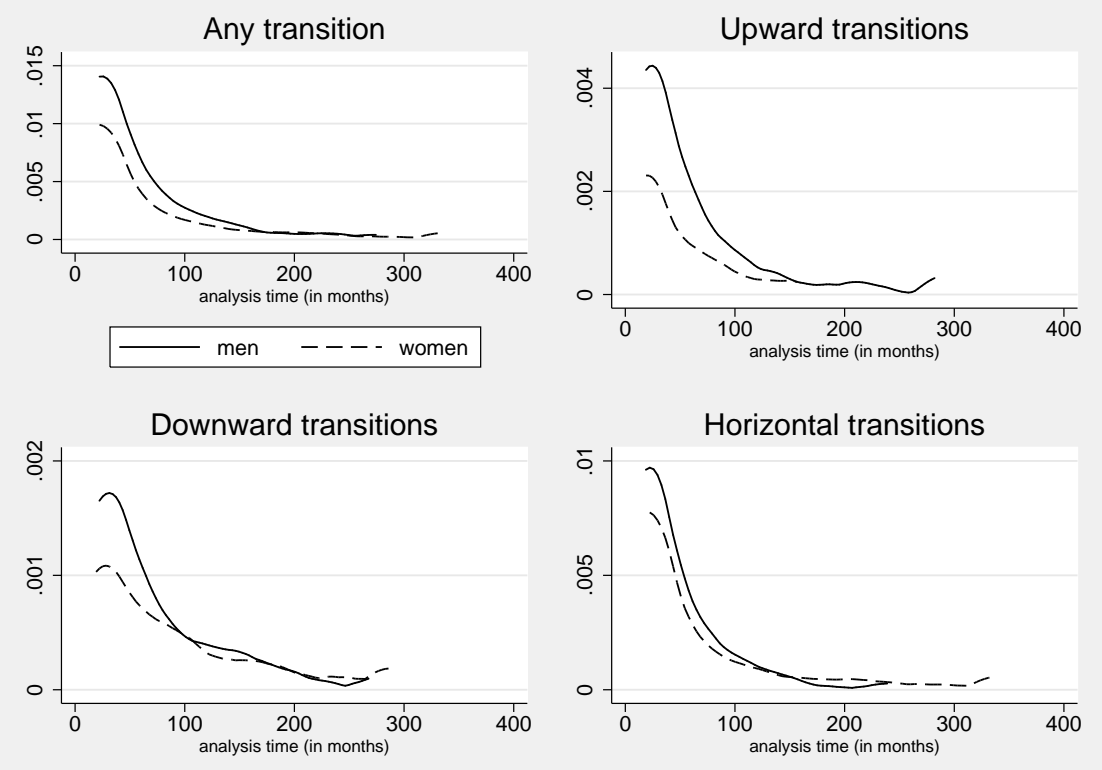

Source: ALWA, own calculations

Figure 2 - Distribution of Parenthood Hazard
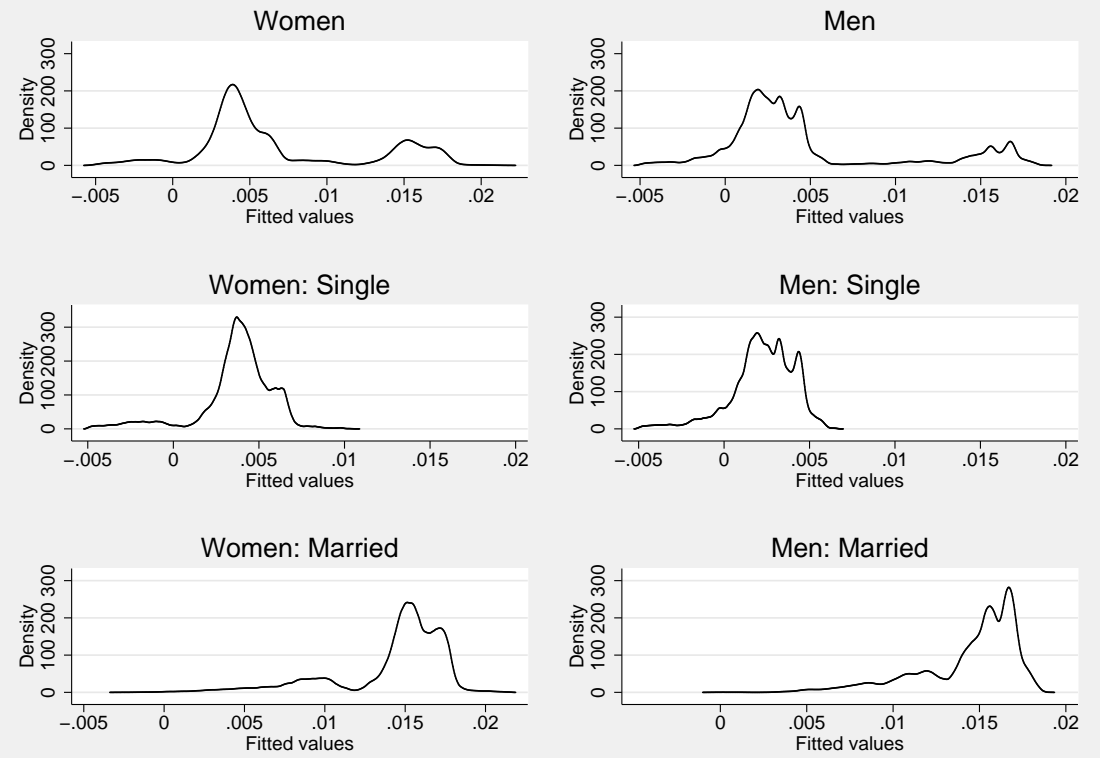

Source: ALWA, own calculations 


\section{Tables}

Table 1 - Career Spell Durations in Months

\begin{tabular}{|c|c|c|c|c|c|c|}
\hline \multicolumn{7}{|c|}{ Dependent variable: number of subordinates } \\
\hline & \multicolumn{3}{|c|}{ Women } & \multicolumn{3}{|c|}{ Men } \\
\hline & Mean & Std. Dev. & $\mathrm{N}$ & Mean & Std. Dev. & $\mathrm{N}$ \\
\hline All spells & 67.61 & 73.23 & 5482 & 62.59 & 72.62 & 6194 \\
\hline Up & 33.32 & 31.89 & 377 & 34.66 & 35.34 & 716 \\
\hline Down & 45.49 & 45.63 & 248 & 40.27 & 39.18 & 364 \\
\hline Horizontal & 30.35 & 36.60 & 1730 & 29.41 & 31.05 & 1961 \\
\hline Censored & 94.11 & 81.99 & 3127 & 92.15 & 86.65 & 3153 \\
\hline \multicolumn{7}{|c|}{ Dependent variable: SIOPS } \\
\hline & \multicolumn{3}{|c|}{ Women } & \multicolumn{3}{|c|}{ Men } \\
\hline & Mean & Std. Dev. & $\mathrm{N}$ & Mean & Std. Dev. & $\mathrm{N}$ \\
\hline All spells & 67.63 & 73.23 & 5480 & 62.58 & 72.57 & 6190 \\
\hline Up & 29.49 & 32.98 & 539 & 31.81 & 35.63 & 685 \\
\hline Down & 31.97 & 33.55 & 403 & 30.91 & 31.25 & 480 \\
\hline Horizontal & 33.24 & 38.39 & 1407 & 32.07 & 32.55 & 1869 \\
\hline Censored & 94.24 & 82.10 & 3131 & 92.14 & 86.58 & 3156 \\
\hline
\end{tabular}


Table 2 - List of Regressors

\begin{tabular}{|c|c|c|c|}
\hline Variable & Description & $\begin{array}{l}\text { Parenthood } \\
\text { Hazard }\end{array}$ & $\begin{array}{l}\text { Career } \\
\text { Hazard }\end{array}$ \\
\hline \multicolumn{4}{|c|}{ Age categories (base category: under 26 years) } \\
\hline AGE2-AGE6 & {$[26 ; 30],[31 ; 35],[36 ; 40],[41 ; 45] ;[46+]$} & $x$ & $x$ \\
\hline \multicolumn{4}{|c|}{ Education (base category: no formal degree) } \\
\hline EDUClow & Vocational training and/or Abitur & $x$ & $x$ \\
\hline EDUChigh & University of applied sciences or University degree & $x$ & \\
\hline EXPER & Work experience in months & $x$ & $x$ \\
\hline EAST & Dummy East Germany & $x$ & $x$ \\
\hline RELIGION & Dummy for being religious (self reported) & $x$ & $x$ \\
\hline MARRIED & Dummy for being married & $x$ & \\
\hline BIRTHRATE & Birth rate per 1,000 inhabitants by year and federal state & $x$ & \\
\hline РОТСА & Potential child allowance & $x$ & \\
\hline PREGHAZ & Pregnancy/parenthood hazard & & $x$ \\
\hline PARTNERhigh & Partner with university degree & & $x$ \\
\hline PARTNERlow & Partner without degree & & $x$ \\
\hline \multicolumn{4}{|c|}{ Duration dependence employment spell in years (base category: less than 3 years) } \\
\hline CAR2-4 & {$[3 ; 5),[5 ; 7),[7+]$} & & $x$ \\
\hline MOBIL & Mobility indicator & & $x$ \\
\hline LDnosub & $\begin{array}{l}\text { Lagged duration dependence: cumulated spells without su- } \\
\text { pervisory responsibilities (in months) }\end{array}$ & & $x$ \\
\hline LDsub & $\begin{array}{l}\text { Lagged duration dependence: cumulated spells with supervi- } \\
\text { sory responsibilities (in months) }\end{array}$ & & $x$ \\
\hline \multicolumn{4}{|c|}{ Current number of subordinates (base category: none) } \\
\hline LEVEL2-5 & {$[1 ; 3],[4 ; 9],[10 ; 24],[25+]$} & & $x$ \\
\hline \multicolumn{4}{|c|}{ Sector Dummies (base category: retailing) } \\
\hline MANUFACT & Manufacturing & & $x$ \\
\hline CONSTRUCTION & Construction & & $x$ \\
\hline AGRICULTURE & Agricultural & & $x$ \\
\hline SERVICE & Service & & $x$ \\
\hline SOCIAL & Social & & $x$ \\
\hline PUBSEC & Dummy for job in public service & & $x$ \\
\hline COMPmaths & Competence measure maths (high values=low competence) & & $x$ \\
\hline COMPverbal & Verbal competence measure (high values=low competence) & & $x$ \\
\hline UNEMPL & Regional unemployment rate & & $x$ \\
\hline UNEMPLdev & Deviation unemployment rate from smooth trend & & $x$ \\
\hline femEMPLOYMENT & Female labor market participation at federal state ${ }^{1}$ & & $x$ \\
\hline FIRMSIZE & Firm size & & $x$ \\
\hline YEAR & (Quadratic) time trend & & $x$ \\
\hline INTER* & Indicators for short interruptive intervals & & $x$ \\
\hline PARTTIME & Indicator for part time work & & $x$ \\
\hline \#INTER & Number if interruptions before current job spell & & $x$ \\
\hline \#PAST JOBS & Number if jobs held before current job spell & & $x$ \\
\hline
\end{tabular}

\footnotetext{
${ }^{1}$ Included in female sample to account for differences in female labor market behavior between federal states.
} 
Table 3 - Mixed Multivariate Proportional Hazard Model: Parenthood Hazard

\begin{tabular}{lllll}
\hline \hline \multicolumn{2}{c}{ Women } & \multicolumn{3}{c}{ Men } \\
\hline AGE2 & $0.123^{*}$ & $(0.0688)$ & $0.244^{* * *}$ & $(0.0916)$ \\
AGE3 & 0.0399 & $(0.107)$ & $0.208^{*}$ & $(0.123)$ \\
AGE4 & $-0.517^{* * *}$ & $(0.194)$ & $-0.332^{*}$ & $(0.183)$ \\
AGE5/6 & $-3.281^{* * *}$ & $(1.020)$ & $-1.136^{* * *}$ & $(0.331)$ \\
AGE6 & & & $-1.824^{* *}$ & $(0.767)$ \\
EDUClow & -0.0317 & $(0.0994)$ & 0.184 & $(0.149)$ \\
EDUChigh & -0.0892 & $(0.126)$ & $0.491^{* * *}$ & $(0.171)$ \\
EXPER & $0.0101^{* * *}$ & $(0.00194)$ & $0.00804^{* * *}$ & $(0.00185)$ \\
EXPER squared & $-0.0000623^{* * *}$ & $(9.96 e-06)$ & $-0.0000364^{* * *}$ & $(8.16 e-06)$ \\
EAST & $0.830^{* * *}$ & $(0.132)$ & $0.481^{* * *}$ & $(0.157)$ \\
RELIGIOUS & $0.272^{* * *}$ & $(0.0720)$ & $0.239^{* * *}$ & $(0.0707)$ \\
BIRTHRATE & $0.109^{* * *}$ & $(0.0258)$ & $0.0666^{* * *}$ & $(0.0253)$ \\
POTCA & $0.0309^{*}$ & $(0.0187)$ & -0.0151 & $(0.0209)$ \\
MARRIED & $1.414^{* * *}$ & $(0.0512)$ & $1.824^{* * *}$ & $(0.0616)$ \\
Constant & $-7.264^{* * *}$ & $(0.299)$ & $-7.505^{* * *}$ & $(0.307)$ \\
\hline N & \multicolumn{5}{c}{276443} & \\
\hline Standard errors in parentheses ; ${ }^{*} p<0.10$, & $* * p<0.05$, & $* * * p<0.01$ & \\
Source: ALWA, own calculations & & & \\
& & & & \\
\hline
\end{tabular}


Table 4 - Mixed Multivariate Proportional Hazard Model (Number of Subordinates)

\begin{tabular}{|c|c|c|c|c|c|c|}
\hline & \multicolumn{3}{|c|}{ Women } & \multicolumn{3}{|c|}{ Men } \\
\hline & Up & Down & Horizontal & Up & Down & Horizontal \\
\hline \multirow[t]{2}{*}{ In(PREGHAZ) } & -0.122 & 0.0401 & $-0.175^{* * *}$ & $0.199^{* * *}$ & 0.00460 & -0.0368 \\
\hline & $(0.107)$ & $(0.136)$ & $(0.0541)$ & $(0.0633)$ & $(0.0899)$ & $(0.0475)$ \\
\hline \multirow[t]{2}{*}{ PARTNERhigh } & $0.335^{* *}$ & 0.0244 & 0.0467 & $0.286^{*}$ & 0.0300 & -0.00708 \\
\hline & $(0.154)$ & $(0.214)$ & $(0.0849)$ & $(0.152)$ & $(0.203)$ & $(0.117)$ \\
\hline \multirow[t]{2}{*}{ PARTNERIow } & $-0.464^{* * *}$ & -0.263 & $-0.146^{* *}$ & $0.242^{* *}$ & -0.149 & 0.0937 \\
\hline & $(0.147)$ & $(0.184)$ & $(0.0647)$ & $(0.102)$ & $(0.142)$ & $(0.0633)$ \\
\hline \multirow[t]{2}{*}{ CAR2 } & 0.00562 & -0.118 & $-0.273^{* * *}$ & 0.0571 & 0.0609 & -0.0921 \\
\hline & $(0.178)$ & $(0.211)$ & $(0.0847)$ & $(0.125)$ & $(0.161)$ & $(0.0838)$ \\
\hline \multirow[t]{2}{*}{ CAR3 } & 0.257 & -0.179 & $-0.565^{* * *}$ & 0.00567 & $-0.541^{* *}$ & $-0.230^{*}$ \\
\hline & $(0.235)$ & $(0.267)$ & $(0.123)$ & $(0.173)$ & $(0.239)$ & $(0.121)$ \\
\hline \multirow[t]{2}{*}{ CAR4 } & -0.136 & $-0.719^{*}$ & $-0.667^{* * *}$ & $-0.653^{* *}$ & $-0.693^{*}$ & $-0.447^{* *}$ \\
\hline & $(0.379)$ & $(0.396)$ & $(0.173)$ & $(0.291)$ & $(0.354)$ & $(0.181)$ \\
\hline \multirow[t]{2}{*}{ EXPER } & -0.00395 & -0.00186 & -0.000904 & -0.00119 & 0.00624 & $-0.00471^{* *}$ \\
\hline & $(0.00472)$ & $(0.00552)$ & $(0.00217)$ & $(0.00346)$ & $(0.00455)$ & $(0.00201)$ \\
\hline \multirow[t]{2}{*}{ EXPER squared } & -0.000027 & 0.00000705 & -0.00000912 & $6.025 e-06$ & -0.0000241 & $6.35 e-06$ \\
\hline & $(0.0000187)$ & $(0.0000185)$ & $(0.00000802)$ & $(0.0000131)$ & $(0.0000158)$ & $(7.61 e-06$ \\
\hline \multirow[t]{2}{*}{ MOBIL } & $0.266^{* * *}$ & $0.380^{* * *}$ & $0.187^{* * *}$ & $0.346^{* * *}$ & $0.314^{* * *}$ & 0.0303 \\
\hline & $(0.0996)$ & $(0.133)$ & $(0.0494)$ & $(0.0740)$ & $(0.0993)$ & $(0.0538)$ \\
\hline \multirow[t]{2}{*}{ LDnosub } & -0.00125 & 0.00276 & 0.000340 & -0.00371 & $-0.00741^{* *}$ & -0.00235 \\
\hline & $(0.00356)$ & $(0.00324)$ & $(0.00149)$ & $(0.00284)$ & $(0.00311)$ & $(0.00162)$ \\
\hline \multirow[t]{2}{*}{ LDsub } & $0.00565^{*}$ & 0.00145 & -0.000913 & 0.000214 & $-0.00931^{* * *}$ & 0.0000500 \\
\hline & $(0.00302)$ & $(0.00325)$ & $(0.00142)$ & $(0.00252)$ & $(0.00329)$ & $(0.00160)$ \\
\hline \multirow[t]{2}{*}{ PUBSEC } & $-0.544^{* * *}$ & -0.0838 & $-0.389^{* * *}$ & -0.295 & -0.252 & $-0.345^{* * *}$ \\
\hline & $(0.192)$ & $(0.242)$ & $(0.0915)$ & $(0.183)$ & $(0.280)$ & $(0.116)$ \\
\hline \multirow[t]{2}{*}{ EDUClow } & -0.126 & $0.861^{*}$ & $0.532^{* * *}$ & $1.0928^{* * *}$ & 0.487 & 0.133 \\
\hline & $(0.273)$ & $(0.479)$ & $(0.147)$ & $(0.318)$ & $(0.411)$ & $(0.110)$ \\
\hline \multirow[t]{2}{*}{ EDUChigh } & -0.0733 & 0.841 & $0.808^{* * *}$ & $1.453^{* * *}$ & 0.635 & 0.407 \\
\hline & $(0.319)$ & $(0.530)$ & $(0.171)$ & $(0.350)$ & $(0.452)$ & $(0.148)$ \\
\hline \multirow[t]{2}{*}{ EAST } & -0.683 & $-1.132^{*}$ & -0.212 & -0.212 & $-0.723^{* *}$ & -0.186 \\
\hline & $(0.433)$ & $(0.620)$ & $(0.205)$ & $(0.247)$ & $(0.331)$ & $(0.131)$ \\
\hline \multirow[t]{2}{*}{ MANUFACT } & -0.253 & 0.164 & -0.134 & 0.0218 & -0.0255 & $-0.186^{* * *}$ \\
\hline & $(0.201)$ & $(0.274)$ & $(0.0891)$ & $(0.130)$ & $(0.194)$ & $(0.0721)$ \\
\hline \multirow[t]{2}{*}{ CONSTRUCTION } & 0.245 & 0.332 & 0.0370 & 0.0164 & 0.337 & -0.0883 \\
\hline & $(0.329)$ & $(0.431)$ & $(0.155)$ & $(0.153)$ & $(0.211)$ & $(0.0789)$ \\
\hline \multirow[t]{2}{*}{ AGRICULTURE } & 0.316 & 0.416 & -0.233 & 0.123 & 0.202 & -0.123 \\
\hline & $(0.316)$ & $(0.366)$ & $(0.169)$ & $(0.201)$ & $(0.299)$ & $(0.113)$ \\
\hline \multirow[t]{2}{*}{ SERVICE } & 0.107 & 0.179 & -0.0867 & 0.137 & 0.0325 & -0.0248 \\
\hline & 0.162 & $(0.212)$ & $(0.0747)$ & $(0.139)$ & $(0.202)$ & $(0.0792)$ \\
\hline \multirow[t]{2}{*}{ SOCIAL } & -0.0261 & -0.260 & -0.106 & -0.256 & 0.213 & -0.107 \\
\hline & $(0.207)$ & $(0.271)$ & $(0.093)$ & $(0.226)$ & $(0.315)$ & $(0.134)$ \\
\hline RELIGION & $-0.505^{* * *}$ & $-0.441^{* *}$ & $-0.151^{* *}$ & -0.0570 & -0.126 & -0.0674 \\
\hline & $(0.137)$ & $(0.188)$ & $(0.0729)$ & $(0.0980)$ & $(0.138)$ & $(0.0578)$ \\
\hline COMPmaths & $-0.144^{* * *}$ & -0.0107 & -0.00498 & $-0.0910^{* *}$ & 0.0817 & -0.0217 \\
\hline & $(0.0516)$ & $(0.0695)$ & $(0.0247)$ & $(0.0448)$ & $(0.0630)$ & $(0.0251)$ \\
\hline COMPverbal & $-0.366^{* * *}$ & 0.00164 & -0.0360 & $-0.152^{* * *}$ & 0.0865 & -0.00675 \\
\hline & $(0.0726)$ & $(0.0939)$ & $(0.0321)$ & $(0.0483)$ & $(0.0653)$ & $(0.0274)$ \\
\hline
\end{tabular}




\begin{tabular}{|c|c|c|c|c|c|c|}
\hline UNEMPL & $\begin{array}{r}-0.00605 \\
(0.0317)\end{array}$ & $\begin{array}{c}0.0454 \\
(0.0430)\end{array}$ & $\begin{array}{r}-0.00845 \\
(0.0156)\end{array}$ & $\begin{array}{c}-0.0157 \\
(0.0195)\end{array}$ & $\begin{array}{c}0.0313 \\
(0.0259)\end{array}$ & $\begin{array}{c}0.0121 \\
(0.0113)\end{array}$ \\
\hline UNEMPLdev & $\begin{array}{r}-0.0159 \\
(0.0496)\end{array}$ & $\begin{array}{c}-0.169^{* * *} \\
(0.0638)\end{array}$ & $\begin{array}{c}-0.0720^{* * *} \\
(0.0237)\end{array}$ & $\begin{array}{c}-0.000941 \\
(0.0349)\end{array}$ & $\begin{array}{r}-0.0202 \\
(0.0497)\end{array}$ & $\begin{array}{c}-0.00144 \\
(0.0206)\end{array}$ \\
\hline femEMPLOYMENT & $\begin{array}{r}-0.00377 \\
(0.0142)\end{array}$ & $\begin{array}{c}0.0208 \\
(0.0193)\end{array}$ & $\begin{array}{c}0.00696 \\
(0.00656)\end{array}$ & & & \\
\hline FIRMSIZE & $\begin{array}{r}-0.0494 \\
(0.0325)\end{array}$ & $\begin{array}{r}-0.121^{* *} \\
(0.0483)\end{array}$ & $\begin{array}{c}-0.114^{* * *} \\
(0.0157)\end{array}$ & $\begin{array}{r}-0.0448^{*} \\
(0.0242)\end{array}$ & $\begin{array}{c}-0.110^{* * *} \\
(0.0390)\end{array}$ & $\begin{array}{c}-0.0952^{* * *} \\
(0.0140)\end{array}$ \\
\hline YEAR & $\begin{array}{c}0.116^{* *} \\
(0.0476)\end{array}$ & $\begin{array}{r}-0.0217 \\
(0.0610)\end{array}$ & $\begin{array}{c}0.0128 \\
(0.0203)\end{array}$ & $\begin{array}{c}0.0364 \\
(0.0317)\end{array}$ & $\begin{array}{c}0.0486 \\
(0.00299)\end{array}$ & $\begin{array}{r}-0.00887 \\
(0.0171)\end{array}$ \\
\hline YEAR squared & $\begin{array}{r}-0.00198^{* *} \\
(0.000939)\end{array}$ & $\begin{array}{c}0.000252 \\
(0.00118)\end{array}$ & $\begin{array}{r}-0.000283 \\
(0.000406)\end{array}$ & $\begin{array}{r}-0.000793 \\
(0.000664)\end{array}$ & $\begin{array}{c}0.000979 \\
(0.000432)\end{array}$ & $\begin{array}{c}0.000276 \\
(0.000362)\end{array}$ \\
\hline LEVEL2 & $\begin{array}{c}-0.581^{* * *} \\
(0.147)\end{array}$ & & $\begin{array}{c}-0.399^{* * *} \\
(0.0644)\end{array}$ & $\begin{array}{c}-0.597^{* * *} \\
(0.119)\end{array}$ & & $\begin{array}{l}-0.208 \\
(0.0615)\end{array}$ \\
\hline LEVEL3 & $\begin{array}{c}-0.438^{* *} \\
(0.177)\end{array}$ & $\begin{array}{c}0.100 \\
(0.187)\end{array}$ & $\begin{array}{c}-1.133^{* * *} \\
(0.116)\end{array}$ & $\begin{array}{c}-0.668^{* * *} \\
(0.125)\end{array}$ & $\begin{array}{c}0.140 \\
(0.173)\end{array}$ & $\begin{array}{c}-0.865^{* * *} \\
(0.0897)\end{array}$ \\
\hline LEVEL4 & $\begin{array}{c}-0.689^{* * *} \\
(0.247)\end{array}$ & $\begin{array}{r}0.0846 \\
(0.217)\end{array}$ & $\begin{array}{c}-1.503^{* * *} \\
(0.184)\end{array}$ & $\begin{array}{c}-1.168^{* * *} \\
(0.174)\end{array}$ & $\begin{array}{c}0.310^{*} \\
(0.184)\end{array}$ & $\begin{array}{c}-1.235^{* * *} \\
(0.132)\end{array}$ \\
\hline LEVEL5 & $\begin{array}{c}-1.191^{* *} \\
(0.467)\end{array}$ & $\begin{array}{c}0.149 \\
(0.295)\end{array}$ & $\begin{array}{c}-2.747^{* * *} \\
(0.582)\end{array}$ & $\begin{array}{c}-1.462^{* * *} \\
(0.266)\end{array}$ & $\begin{array}{l}0.649^{* * *} \\
(0.215)\end{array}$ & $\begin{array}{c}-1.652^{* * *} \\
(0.247)\end{array}$ \\
\hline AGE2 & $\begin{array}{c}0.231 \\
(0.159)\end{array}$ & $\begin{array}{c}-0.0293 \\
(0.220)\end{array}$ & $\begin{array}{c}0.0445 \\
(0.0795)\end{array}$ & $\begin{array}{r}-0.167 \\
(0.125)\end{array}$ & $\begin{array}{r}-0.103 \\
(0.179)\end{array}$ & $\begin{array}{r}-0.0934 \\
(0.0778)\end{array}$ \\
\hline AGE3 & $\begin{array}{c}0.108 \\
(0.260)\end{array}$ & $\begin{array}{c}0.144 \\
(0.336)\end{array}$ & $\begin{array}{c}-0.285^{* *} \\
(0.139)\end{array}$ & $\begin{array}{c}-0.238 \\
(0.186)\end{array}$ & $\begin{array}{l}0.00475 \\
(0.253)\end{array}$ & $\begin{array}{r}-0.0997 \\
(0.118)\end{array}$ \\
\hline AGE4 & $\begin{array}{c}0.396 \\
(0.389)\end{array}$ & $\begin{array}{c}0.735 \\
(0.470)\end{array}$ & $\begin{array}{c}0.132 \\
(0.198)\end{array}$ & $\begin{array}{r}-0.468 \\
(0.292)\end{array}$ & $\begin{array}{c}0.110 \\
(0.348)\end{array}$ & $\begin{array}{c}-0.500^{* * *} \\
(0.187)\end{array}$ \\
\hline AGE56 & $\begin{array}{c}0.350 \\
(0.707)\end{array}$ & $\begin{array}{c}0.306 \\
(0.894)\end{array}$ & $\begin{array}{r}-0.479 \\
(0.395)\end{array}$ & $\begin{array}{r}-0.665 \\
(0.487)\end{array}$ & $\begin{array}{c}0.121 \\
(0.528)\end{array}$ & $\begin{array}{c}-0.680^{* *} \\
(0.306)\end{array}$ \\
\hline AGE6 & & & & $\begin{array}{c}-1.666 \\
(1.154)\end{array}$ & $\begin{array}{r}0.0537 \\
(0.974)\end{array}$ & $\begin{array}{c}-0.940^{*} \\
(0.507)\end{array}$ \\
\hline INTERunempl & $\begin{array}{l}2.245^{* * *} \\
(0.163)\end{array}$ & $\begin{array}{l}3.374^{* * *} \\
(0.202)\end{array}$ & $\begin{array}{l}2.789^{* * *} \\
(0.0699)\end{array}$ & & & \\
\hline INTERser.oth & $\begin{array}{r}-0.660 \\
(1.004)\end{array}$ & $\begin{array}{l}1.501^{* *} \\
(0.600)\end{array}$ & $\begin{array}{l}1.308^{* * *} \\
(0.193)\end{array}$ & & & \\
\hline INTERany $^{1}$ & & & & $\begin{array}{l}1.446^{* * *} \\
(0.106)\end{array}$ & $\begin{array}{l}2.308^{* * *} \\
(0.146)\end{array}$ & $\begin{array}{l}2.439^{* * *} \\
(0.0518)\end{array}$ \\
\hline PARTTIME & $\begin{array}{r}-0.106 \\
(0.305)\end{array}$ & $\begin{array}{c}0.107 \\
(0.484)\end{array}$ & $\begin{array}{c}0.235^{*} \\
(0.128)\end{array}$ & $\begin{array}{c}0.351 \\
(0.321)\end{array}$ & $\begin{array}{l}1.0418^{* * *} \\
(0.398)\end{array}$ & $\begin{array}{l}0.683^{* * *} \\
(0.176)\end{array}$ \\
\hline \#INTER & $\begin{array}{c}-0.104 \\
(0.207)\end{array}$ & $\begin{array}{c}-0.372 \\
(0.301)\end{array}$ & $\begin{array}{c}-0.134 \\
(0.107)\end{array}$ & $\begin{array}{c}-0.203^{*} \\
(0.119)\end{array}$ & $\begin{array}{l}0.00411 \\
(0.139)\end{array}$ & $\begin{array}{c}-0.144^{* *} \\
(0.0618)\end{array}$ \\
\hline \#PAST JOBS & $\begin{array}{r}-0.0320 \\
(0.072) \\
\end{array}$ & $\begin{array}{c}-0.287^{* * *} \\
(0.103)\end{array}$ & $\begin{array}{c}-0.0741^{*} \\
(0.0432) \\
\end{array}$ & $\begin{array}{c}0.0641 \\
(0.0478) \\
\end{array}$ & $\begin{array}{c}0.155^{* * *} \\
(0.0561) \\
\end{array}$ & $\begin{array}{c}0.185^{* * *} \\
(0.0239) \\
\end{array}$ \\
\hline$v^{1}$ & $\begin{array}{c}-6.335^{* * *} \\
(1.085)\end{array}$ & $\begin{array}{c}-6.978^{* * *} \\
(1.479)\end{array}$ & $\begin{array}{c}-5.838^{* * *} \\
(0.516)\end{array}$ & $\begin{array}{c}-4.758^{* * *} \\
(0.673)\end{array}$ & $\begin{array}{c}-6.871^{* * *} \\
(0.975)\end{array}$ & $\begin{array}{c}-4.843^{* * *} \\
(0.413)\end{array}$ \\
\hline$v^{2}$ & $\begin{array}{c}-4.990^{* * *} \\
(1.110)\end{array}$ & $\begin{array}{c}-5.211^{* * *} \\
(1.478)\end{array}$ & $\begin{array}{c}-4.817^{* * *} \\
(0.532)\end{array}$ & $\begin{array}{c}-6.514^{* * *} \\
(0.961)\end{array}$ & $\begin{array}{c}-9.139^{* * *} \\
(1.743)\end{array}$ & $\begin{array}{c}-4.431^{* * *} \\
(0.417)\end{array}$ \\
\hline$p=\operatorname{Prob}\left(v=v^{1}\right)$ & & $\begin{array}{c}0.891^{* * *} \\
(0.0332)\end{array}$ & & & $\begin{array}{c}0.663^{* * *} \\
(0.120)\end{array}$ & \\
\hline
\end{tabular}

Continued on next page.. 


$N=273207 \quad 276443$

1 Summarizes interruptions due to military service, unemployment and other in male sample Standard errors in parentheses ${ }^{*} p<0.10,{ }^{* *} p<0.05,{ }^{* * *} p<0.01$

Source: ALWA, own calculations 
Table 5 - Mixed Multivariate Proportional Hazard Model (SIOPS)

\begin{tabular}{|c|c|c|c|c|c|c|}
\hline & \multicolumn{3}{|c|}{ Women } & \multicolumn{3}{|c|}{ Men } \\
\hline & Up & Down & Horizontal & Up & Down & Horizontal \\
\hline \multirow[t]{2}{*}{$\ln ($ PREGHAZ) } & -0.111 & 0.0521 & $-0.167^{* * *}$ & $0.184^{* *}$ & -0.0239 & -0.0500 \\
\hline & $(0.107)$ & $(0.135)$ & $(0.0538)$ & $(0.066)$ & $(0.095)$ & $(0.060)$ \\
\hline \multirow[t]{2}{*}{ PARTNERhigh } & $0.348^{* *}$ & 0.0106 & 0.0587 & $0.325^{*}$ & 0.196 & -0.0821 \\
\hline & $(0.154)$ & $(0.212)$ & $(0.0846)$ & $(0.155)$ & $(0.213)$ & $(0.143)$ \\
\hline \multirow[t]{2}{*}{ PARTNERIow } & $-0.451^{* * *}$ & -0.261 & $-0.136^{* *}$ & 0.211 & 0.0134 & 0.0306 \\
\hline & $(0.147)$ & $(0.183)$ & $(0.0649)$ & $(0.110)$ & $(0.152)$ & $(0.086)$ \\
\hline \multirow[t]{2}{*}{ CAR2 } & -0.0113 & -0.143 & $-0.285^{* * *}$ & 0.07845 & -0.0344 & -0.00314 \\
\hline & $(0.178)$ & $(0.210)$ & $(0.0848)$ & $(0.130)$ & $(0.178)$ & $(0.105)$ \\
\hline \multirow[t]{2}{*}{ CAR3 } & 0.244 & -0.178 & $-0.577^{* * *}$ & 0.0450 & $-0.510^{*}$ & -0.0949 \\
\hline & $(0.234)$ & $(0.265)$ & $(0.123)$ & $(0.174)$ & $(0.258)$ & $(0.145)$ \\
\hline \multirow[t]{2}{*}{ CAR4 } & -0.155 & $-0.672^{*}$ & $-0.666^{* * *}$ & -0.549 & -0.479 & -0.351 \\
\hline & $(0.379)$ & $(0.395)$ & $(0.173)$ & $(0.290)$ & $(0.372)$ & $(0.220)$ \\
\hline \multirow[t]{2}{*}{ EXPER } & -0.00413 & -0.00227 & -0.00125 & -0.000794 & 0.00683 & $-0.00927^{* *}$ \\
\hline & $(0.00469)$ & $(0.00554)$ & $(0.00215)$ & $(0.003)$ & $(0.005)$ & $(0.002)$ \\
\hline \multirow[t]{2}{*}{ EXPER squared } & -0.0000249 & 0.00000899 & -0.00000714 & -0.0000053 & $-0.0000396^{*}$ & 0.0000196 \\
\hline & $(0.0000186)$ & $(0.0000185)$ & $(0.00000800)$ & $(0.000)$ & $(0.000)$ & $(0.000)$ \\
\hline \multirow[t]{2}{*}{ MOBIL } & $0.258^{* * *}$ & $0.374^{* * *}$ & $0.178^{* * *}$ & $0.277^{* *}$ & $0.367^{* * *}$ & $0.183^{* *}$ \\
\hline & $(0.0999)$ & $(0.133)$ & $(0.0497)$ & $(0.087)$ & $(0.098)$ & $(0.070)$ \\
\hline \multirow[t]{2}{*}{ LDnosub } & -0.00128 & 0.00329 & 0.000306 & 0.000239 & 0.00227 & -0.00161 \\
\hline & $(0.00350)$ & $(0.00322)$ & $(0.00149)$ & $(0.003)$ & $(0.003)$ & $(0.002)$ \\
\hline \multirow[t]{2}{*}{ LDsub } & $0.00560^{*}$ & 0.00177 & -0.00102 & 0.00191 & 0.000727 & -0.0000278 \\
\hline & $(0.00301)$ & $(0.00321)$ & $(0.00144)$ & $(0.002)$ & $(0.003)$ & $(0.002)$ \\
\hline \multirow[t]{2}{*}{ PUBSEC } & $-0.574^{* * *}$ & -0.129 & $-0.402^{* * *}$ & -0.336 & -0.426 & $-0.613^{* * *}$ \\
\hline & $(0.191)$ & $(0.241)$ & $(0.0915)$ & $(0.195)$ & $(0.280)$ & $(0.162)$ \\
\hline \multirow[t]{2}{*}{ EDUClow $^{\dagger}$} & -0.107 & $0.889^{*}$ & $0.541^{* * *}$ & $0.0875^{*}$ & 0.0152 & 0.0551 \\
\hline & $(0.274)$ & $(0.473)$ & $(0.148)$ & $(0.042)$ & $(0.058)$ & $(0.035)$ \\
\hline \multirow[t]{2}{*}{ EDUChigh } & -0.0437 & $0.931^{*}$ & $0.813^{* * *}$ & & & \\
\hline & $(0.319)$ & $(0.522)$ & $(0.171)$ & & & \\
\hline \multirow[t]{2}{*}{ EAST } & -0.634 & -1.016 & -0.161 & -0.171 & -0.556 & -0.369 \\
\hline & $(0.437)$ & $(0.626)$ & $(0.206)$ & $(0.282)$ & $(0.374)$ & $(0.205)$ \\
\hline \multirow[t]{2}{*}{ MANUFACT } & -0.215 & 0.214 & -0.103 & 0.0275 & -0.123 & $-0.389^{* * *}$ \\
\hline & $(0.201)$ & $(0.243)$ & $(0.271)$ & $(0.139)$ & $(0.200)$ & $(0.104)$ \\
\hline \multirow[t]{2}{*}{ CONSTRUCTION } & 0.266 & 0.296 & 0.0783 & -0.0566 & 0.0511 & $-0.375^{* *}$ \\
\hline & $(0.329)$ & $(0.424)$ & $(0.154)$ & $(0.168)$ & $(0.230)$ & $(0.123)$ \\
\hline \multirow[t]{2}{*}{ AGRICULTURE } & 0.297 & 0.369 & -0.244 & -0.0277 & -0.0380 & -0.173 \\
\hline & $(0.316)$ & $(0.360)$ & $(0.169)$ & $(0.225)$ & $(0.323)$ & $(0.163)$ \\
\hline \multirow[t]{2}{*}{ SERVICE } & 0.132 & 0.198 & -0.0715 & 0.174 & -0.0136 & -0.181 \\
\hline & $(0.162)$ & $(0.210)$ & $(0.0745)$ & $(0.148)$ & $(0.209)$ & $(0.111)$ \\
\hline \multirow[t]{2}{*}{ SOCIAL } & 0.00000116 & -0.226 & -0.0937 & -0.256 & 0.197 & -0.192 \\
\hline & $(0.206)$ & $(0.269)$ & $(0.0928)$ & $(0.237)$ & $(0.320)$ & $(0.183)$ \\
\hline RELIGION & $-0.505^{* * *}$ & $-0.444^{* *}$ & $-0.150^{* *}$ & -0.128 & -0.0457 & -0.119 \\
\hline & $(0.136)$ & $(0.184)$ & $(0.0726)$ & $(0.101)$ & $(0.145)$ & $(0.083)$ \\
\hline COMPmaths & $-0.148^{* * *}$ & -0.00169 & -0.00881 & -0.0641 & -0.00319 & -0.00243 \\
\hline & $(0.0515)$ & $(0.0687)$ & $(0.0246)$ & $(0.047)$ & $(0.065)$ & $(0.037)$ \\
\hline COMPverbal & $-0.361^{* * *}$ & 0.00661 & -0.0323 & $-0.132^{* *}$ & -0.0403 & -0.0333 \\
\hline & $(0.0730)$ & $(0.0930)$ & $(0.0322)$ & $(0.051)$ & $(0.072)$ & $(0.041)$ \\
\hline
\end{tabular}




\begin{tabular}{|c|c|c|c|c|c|c|}
\hline \multirow[t]{2}{*}{ UNEMPL } & -0.00545 & 0.0426 & -0.00669 & $-0.0417^{*}$ & 0.0300 & 0.0127 \\
\hline & $(0.0320)$ & $(0.0435)$ & $(0.0157)$ & $(0.021)$ & $(0.028)$ & $(0.017)$ \\
\hline \multirow[t]{2}{*}{ UNEMPLdev } & -0.00839 & $-0.153^{* *}$ & $-0.0668^{* * *}$ & 0.0152 & -0.0777 & 0.00426 \\
\hline & $(0.0497)$ & $(0.0639)$ & $(0.0237)$ & $(0.038)$ & $(0.054)$ & $(0.029)$ \\
\hline \multirow[t]{2}{*}{ FIRMSIZE } & $-0.0620^{*}$ & $-0.130^{* * *}$ & $-0.126^{* * *}$ & $-0.0569^{*}$ & $-0.0797^{*}$ & $-0.166^{* * *}$ \\
\hline & $(0.0325)$ & $(0.0480)$ & $(0.0157)$ & $(0.026)$ & $(0.039)$ & $(0.020)$ \\
\hline \multirow[t]{2}{*}{ YEAR } & $0.117^{* *}$ & -0.0244 & 0.0150 & 0.0326 & -0.0273 & -0.0280 \\
\hline & $(0.0476)$ & $(0.0608)$ & $(0.0203)$ & $(0.036)$ & $(0.054)$ & $(0.025)$ \\
\hline \multirow[t]{2}{*}{ YEAR squared } & $-0.00196^{* *}$ & 0.000333 & -0.000301 & -0.000733 & 0.000779 & 0.000553 \\
\hline & $(0.000939)$ & $(0.00118)$ & $(0.000406)$ & $(0.001)$ & $(0.001)$ & $(0.001)$ \\
\hline \multirow[t]{2}{*}{ LEVEL2 } & $-0.600^{* * *}$ & & $-0.409^{* * *}$ & $-0.505^{* * *}$ & $0.761^{* * *}$ & $-0.511^{* * *}$ \\
\hline & $(0.147)$ & & $(0.0645)$ & $(0.127)$ & $(0.217)$ & $(0.091)$ \\
\hline \multirow[t]{2}{*}{ LEVEL3 } & $-0.460^{* * *}$ & 0.116 & $-1.145^{* * *}$ & $-0.512^{* * *}$ & $1.827^{* * *}$ & $-1.308^{* * *}$ \\
\hline & $(0.177)$ & $(0.185)$ & $(0.116)$ & $(0.125)$ & $(0.173)$ & $(0.130)$ \\
\hline \multirow[t]{2}{*}{ LEVEL4 } & $-0.688^{* * *}$ & 0.137 & $-1.491^{* * *}$ & $-0.964^{* * *}$ & $2.009^{* * *}$ & $-2.096^{* * *}$ \\
\hline & $(0.247)$ & $(0.214)$ & $(0.184)$ & $(0.178)$ & $(0.183)$ & $(0.238)$ \\
\hline \multirow[t]{2}{*}{ LEVEL5 ${ }^{\ddagger}$} & $-1.187^{* *}$ & 0.189 & $-2.738^{* * *}$ & & & \\
\hline & $(0.468)$ & $(0.290)$ & $(0.582)$ & & & \\
\hline \multirow[t]{2}{*}{ AGE2 } & 0.209 & -0.0822 & 0.0281 & -0.230 & -0.0259 & -0.0334 \\
\hline & $(0.158)$ & $(0.216)$ & $(0.0788)$ & $(0.135)$ & $(0.196)$ & $(0.104)$ \\
\hline \multirow[t]{2}{*}{ AGE3 } & 0.0879 & 0.115 & $-0.292^{* *}$ & -0.263 & 0.0363 & 0.148 \\
\hline & $(0.257)$ & $(0.331)$ & $(0.138)$ & $(0.198)$ & $(0.277)$ & $(0.155)$ \\
\hline \multirow[t]{2}{*}{ AGE4 } & 0.369 & 0.693 & 0.130 & -0.547 & 0.0347 & -0.0984 \\
\hline & $(0.387)$ & $(0.464)$ & $(0.198)$ & $(0.312)$ & $(0.380)$ & $(0.242)$ \\
\hline \multirow[t]{2}{*}{ AGE56 } & 0.367 & 0.234 & -0.495 & -0.654 & 0.241 & -0.412 \\
\hline & $(0.707)$ & $(0.885)$ & $(0.395)$ & $(0.521)$ & $(0.554)$ & $(0.387)$ \\
\hline \multirow[t]{2}{*}{ AGE6 } & & & & -1.217 & -0.316 & -0.530 \\
\hline & & & & $(1.162)$ & $(1.187)$ & $(0.628)$ \\
\hline \multirow[t]{2}{*}{ INTERser.oth.unempl. ${ }^{\ddagger}$} & $2.128^{* * *}$ & $3.041^{* * *}$ & $2.532^{* * *}$ & & & \\
\hline & $(0.159)$ & $(0.191)$ & $(0.0662)$ & & & \\
\hline \multirow[t]{2}{*}{ PARTTIME } & -0.382 & -0.287 & 0.0129 & 0.402 & $0.817^{*}$ & $0.671^{* * *}$ \\
\hline & $(0.293)$ & $(0.481)$ & $(0.114)$ & $(0.312)$ & $(0.361)$ & $(0.196)$ \\
\hline \multirow[t]{2}{*}{ \#INTER } & -0.0381 & -0.331 & -0.0937 & -0.210 & 0.00481 & 0.0133 \\
\hline & $(0.208)$ & $(0.295)$ & $(0.106)$ & $(0.121)$ & $(0.135)$ & $(0.086)$ \\
\hline \multirow[t]{2}{*}{ \#PAST JOBS $\ddagger$} & -0.0369 & $-0.272^{* * *}$ & $-0.0726^{*}$ & & & \\
\hline & $(0.0715)$ & $(0.102)$ & $(0.0414)$ & & & \\
\hline \multirow[t]{2}{*}{ femEMPLOYMENT } & -0.00528 & 0.0194 & 0.00570 & & & \\
\hline & $(0.0143)$ & $(0.0193)$ & $(0.00659)$ & & & \\
\hline \multirow[t]{2}{*}{$v^{1}$} & $-6.182^{* * *}$ & $-6.791^{* * *}$ & $-5.720^{* * *}$ & $-4.0463^{* * *}$ & $-7.598^{* * *}$ & $-3.009^{* * *}$ \\
\hline & $(1.089)$ & $(1.471)$ & $(0.518)$ & $(0.687)$ & $(1.015)$ & $(0.539)$ \\
\hline \multirow[t]{2}{*}{$v^{2}$} & $-4.760^{* * *}$ & $-5.047^{* * *}$ & $-4.639^{* * *}$ & $-3.980^{* * *}$ & $-7.822^{* * *}$ & $-4.428^{* * *}$ \\
\hline & $(1.112)$ & $(1.471)$ & $(0.532)$ & $(0.654)$ & $(0.978)$ & $(0.599)$ \\
\hline \multirow[t]{2}{*}{$p=\operatorname{Prob}\left(v=v^{1}\right)$} & & $0.906^{* * *}$ & & & $0.416^{* * *}$ & \\
\hline & & $(0.0283)$ & & & $(0.145)$ & \\
\hline$N$ & & 273162 & & & 263374 & \\
\hline
\end{tabular}


Table 6 - Pregnancy Hazard: Model Comparison

\begin{tabular}{|c|c|c|c|c|c|c|}
\hline \multirow[b]{3}{*}{ MMPHM } & \multicolumn{6}{|c|}{ Women } \\
\hline & \multicolumn{2}{|l|}{ Up } & \multicolumn{2}{|c|}{ Down } & \multicolumn{2}{|c|}{ Horizontal } \\
\hline & -0.122 & $(0.107)$ & 0.0401 & $(0.136)$ & $-0.175^{* * *}$ & $(0.0541$ \\
\hline Person FE & -0.0351 & $(0.0284)$ & -0.0172 & $(0.0717)$ & $-0.243^{* * *}$ & $(0.0560)$ \\
\hline Spell FE & $-0.0546^{* *}$ & $(0.0224)$ & 0.0441 & $(0.0745)$ & $-0.191^{* * *}$ & $(0.0479)$ \\
\hline MMPHM (SIOPS) & -0.111 & $(0.107)$ & 0.0521 & $(0.135)$ & $-0.167^{* * *}$ & $(0.0538$ \\
\hline Person FE (SIOPS) & $-0.0814^{* * *}$ & $(0.0295)$ & -0.00233 & $(0.0395)$ & $-0.214^{* * *}$ & $(0.0502$ \\
\hline \multirow[t]{3}{*}{ Spell FE (SIOPS) } & $-0.0562^{* *}$ & $(0.0261)$ & -0.00979 & $(0.0404)$ & $-0.183^{* * *}$ & $(0.0459)$ \\
\hline & \multicolumn{6}{|c|}{ Men } \\
\hline & \multicolumn{2}{|l|}{ Up } & \multicolumn{2}{|c|}{ Down } & \multicolumn{2}{|c|}{ Horizontal } \\
\hline MMPHM & $0.199^{* * *}$ & $(0.0633)$ & 0.00460 & $(0.0899)$ & -0.0368 & $(0.0475$ \\
\hline Person FE & $0.0820^{* * *}$ & $(0.0375)$ & -0.0390 & $(0.0538)$ & -0.0264 & $(0.0485)$ \\
\hline Spell FE & $0.117^{* * *}$ & $(0.0386)$ & 0.0403 & $(0.0570)$ & 0.0388 & $(0.0463)$ \\
\hline MMPHM (SIOPS) & $0.184^{* *}$ & $(0.066)$ & -0.0239 & $(0.095)$ & -0.0500 & $(0.060)$ \\
\hline Person FE (SIOPS) & 0.0422 & $(0.0310)$ & -0.00329 & $(0.0310)$ & -0.0579 & $(0.0497$ \\
\hline Spell FE (SIOPS) & $0.0796^{* *}$ & $(0.0349)$ & 0.00816 & $(0.0354)$ & 0.0289 & $(0.0474)$ \\
\hline
\end{tabular}

Standard errors in parentheses ${ }^{*} p<0.10,{ }^{* *} p<0.05,{ }^{* * *} p<0.01$

Source: ALWA, own calculations 


\section{Appendix}

Table 7 - Summary Statistics: Female and Male Sample

\begin{tabular}{|c|c|c|c|c|}
\hline \multirow[b]{2}{*}{ Variable } & \multicolumn{2}{|c|}{ Female } & \multicolumn{2}{|c|}{ Male } \\
\hline & Mean & Std. Dev. & Mean & Std. Dev. \\
\hline AGE2 & 0.278 & 0.448 & 0.288 & 0.453 \\
\hline AGE3 & 0.141 & 0.348 & 0.186 & 0.389 \\
\hline AGE4 & 0.074 & 0.262 & 0.101 & 0.301 \\
\hline AGE5 & 0.038 & 0.192 & 0.047 & 0.212 \\
\hline AGE6 & 0.014 & 0.117 & 0.016 & 0.125 \\
\hline Age & 27.527 & 6.473 & 28.779 & 6.608 \\
\hline EDUClow & 0.804 & 0.397 & 0.763 & 0.425 \\
\hline EDUChigh & 0.142 & 0.35 & 0.19 & 0.392 \\
\hline EXPER & 80.341 & 70.911 & 81.463 & 70.114 \\
\hline EAST & 0.034 & 0.182 & 0.051 & 0.22 \\
\hline RELIGION & 0.820 & 0.384 & 0.74 & 0.439 \\
\hline BIRTHRATE & 9.967 & 1.104 & 9.868 & 1.18 \\
\hline РОТСA & 3.02 & 1.641 & 3.242 & 1.687 \\
\hline MARRIED & 0.287 & 0.453 & 0.198 & 0.398 \\
\hline PARTNERhigh & 0.16 & 0.367 & 0.079 & 0.269 \\
\hline PARTNERlow & 0.353 & 0.478 & 0.311 & 0.463 \\
\hline MOBIL & 0.148 & 0.399 & 0.125 & 0.394 \\
\hline LDnosub & 9.15 & 26.364 & 11.348 & 27.643 \\
\hline LDsub & 8.283 & 27.615 & 8.85 & 25.483 \\
\hline PUBSEC & 0.292 & 0.455 & 0.193 & 0.395 \\
\hline MANUFACT & 0.175 & 0.38 & 0.339 & 0.473 \\
\hline CONSTRUCTION & 0.023 & 0.15 & 0.126 & 0.332 \\
\hline AGRICULTURE & 0.027 & 0.161 & 0.046 & 0.209 \\
\hline SERVICE & 0.285 & 0.452 & 0.192 & 0.394 \\
\hline SOCIAL & 0.323 & 0.468 & 0.163 & 0.369 \\
\hline COMPmaths & 2.713 & 1.067 & 2.207 & 0.96 \\
\hline COMPverbal & 2.033 & 0.836 & 2.179 & 0.882 \\
\hline UNEMPL & 8.734 & 3.14 & 9.129 & 3.254 \\
\hline UNEMPLdev & 0.269 & 1.355 & 0.283 & 1.343 \\
\hline femEMPLOYMENT & 58.080 & 7.115 & 4.891 & 1.755 \\
\hline FIRMSIZE & 4.428 & 1.805 & 0.013 & 0.113 \\
\hline INTERunempl & 0.011 & 0.104 & 0.028 & 0.164 \\
\hline INTERser.oth & 0.004 & 0.066 & 0.006 & 0.075 \\
\hline PARTTIME & 0.037 & 0.19 & 0.013 & 0.113 \\
\hline LEVEL2 & 0.237 & 0.425 & 0.169 & 0.375 \\
\hline LEVEL3 & 0.131 & 0.337 & 0.171 & 0.377 \\
\hline LEVEL4 & 0.081 & 0.272 & 0.117 & 0.322 \\
\hline LEVEL5 & 0.029 & 0.168 & 0.059 & 0.236 \\
\hline \#INTER & 0.101 & 0.342 & 0.183 & 0.475 \\
\hline \#PAST JOBS & 0.881 & 1.213 & 1.155 & 1.386 \\
\hline Number of subordinates & 4.425 & 17.928 & 9.908 & 100.085 \\
\hline SIOPS & 44.400 & 10.295 & 43.388 & 11.419 \\
\hline $\mathrm{N}$ & & 3207 & & 6443 \\
\hline
\end{tabular}


Table 8 - Person Fixed Effects Estimation (Number of Subordinates)

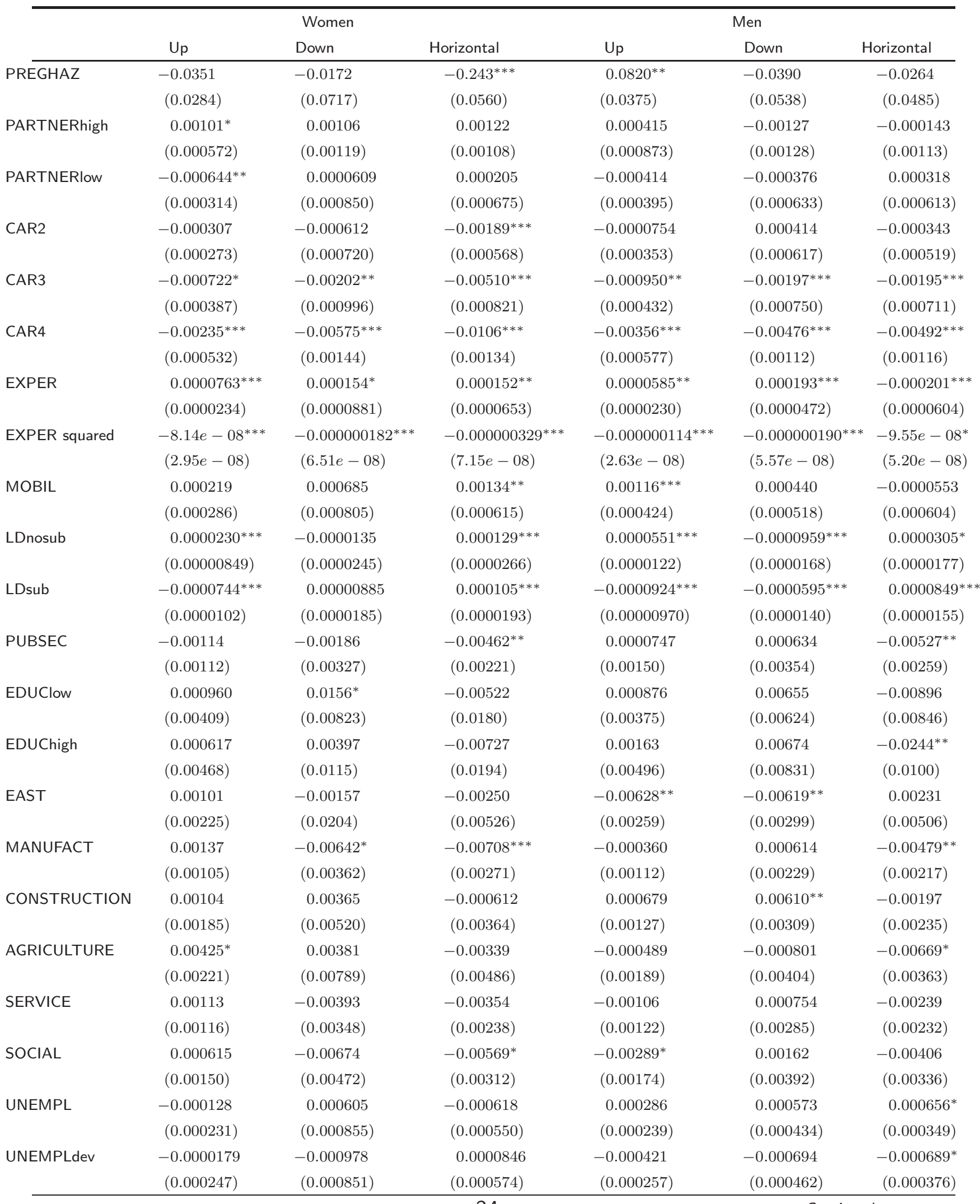




\begin{tabular}{|c|c|c|c|c|c|c|}
\hline femEMPLOYMENT & $\begin{array}{r}-0.0000845 \\
(0.0000807)\end{array}$ & $\begin{array}{c}0.000165 \\
(0.000195)\end{array}$ & $\begin{array}{c}0.000243 \\
(0.000178)\end{array}$ & & & \\
\hline FIRMSIZE & $\begin{array}{r}-0.000324^{*} \\
(0.000195)\end{array}$ & $\begin{array}{r}-0.00115^{* *} \\
(0.000581)\end{array}$ & $\begin{array}{r}-0.000770^{*} \\
(0.000431)\end{array}$ & $\begin{array}{c}-0.000453^{* *} \\
(0.000229)\end{array}$ & $\begin{array}{r}-0.000388 \\
(0.000418)\end{array}$ & $\begin{array}{c}-0.00119^{* * *} \\
(0.000379)\end{array}$ \\
\hline YEAR & $\begin{array}{r}-0.000215 \\
(0.000287)\end{array}$ & $\begin{array}{r}-0.000996 \\
(0.00112)\end{array}$ & $\begin{array}{c}0.000476 \\
(0.000835)\end{array}$ & $\begin{array}{c}0.000170 \\
(0.000292)\end{array}$ & $\begin{array}{c}-0.00166^{* * *} \\
(0.000598)\end{array}$ & $\begin{array}{c}0.00367^{* * *} \\
(0.000769)\end{array}$ \\
\hline YEAR squared & $\begin{array}{r}-0.00000174 \\
(0.00000305)\end{array}$ & $\begin{array}{c}0.00000511 \\
(0.00000884)\end{array}$ & $\begin{array}{r}-0.00000372 \\
(0.00000710)\end{array}$ & $\begin{array}{c}7.12 e-07 \\
(3.63 e-06)\end{array}$ & $\begin{array}{c}0.0000119^{*} \\
(0.00000637)\end{array}$ & $\begin{array}{r}0.00000133 \\
(0.00000622\end{array}$ \\
\hline LEVEL2 & $\begin{array}{c}-0.00696^{* * *} \\
(0.000948)\end{array}$ & & $\begin{array}{c}-0.00868^{* * *} \\
(0.00185)\end{array}$ & $\begin{array}{c}-0.00959^{* * *} \\
(0.00107)\end{array}$ & & $\begin{array}{c}-0.00320^{* *} \\
(0.00163)\end{array}$ \\
\hline LEVEL3 & $\begin{array}{c}-0.0154^{* * *} \\
(0.00122)\end{array}$ & $\begin{array}{l}0.0172^{* * *} \\
(0.00190)\end{array}$ & $\begin{array}{c}-0.00730^{* * *} \\
(0.00199)\end{array}$ & $\begin{array}{c}-0.0168^{* * *} \\
(0.00111)\end{array}$ & $\begin{array}{l}0.0161^{* * *} \\
(0.00147)\end{array}$ & $\begin{array}{r}-0.00242^{*} \\
(0.00132)\end{array}$ \\
\hline LEVEL4 & $\begin{array}{c}-0.0213^{* * *} \\
(0.00158)\end{array}$ & $\begin{array}{l}0.0216^{* * *} \\
(0.00198)\end{array}$ & $\begin{array}{c}-0.00509^{* *} \\
(0.00201)\end{array}$ & $\begin{array}{c}-0.0226^{* * *} \\
(0.00142)\end{array}$ & $\begin{array}{l}0.0204^{* * *} \\
(0.00169)\end{array}$ & $\begin{array}{r}0.000680 \\
(0.00162)\end{array}$ \\
\hline LEVEL5 & $\begin{array}{c}-0.0239^{* * *} \\
(0.00226)\end{array}$ & $\begin{array}{l}0.0258^{* * *} \\
(0.00281)\end{array}$ & $\begin{array}{c}0.00367 \\
(0.00297)\end{array}$ & $\begin{array}{c}-0.0258^{* * *} \\
(0.00174)\end{array}$ & $\begin{array}{l}0.0245^{* * *} \\
(0.00190)\end{array}$ & $\begin{array}{c}0.000493 \\
(0.00168)\end{array}$ \\
\hline AGE2 & $\begin{array}{c}0.000456 \\
(0.000341)\end{array}$ & $\begin{array}{r}0.0000192 \\
(0.000842)\end{array}$ & $\begin{array}{c}0.000994 \\
(0.000679)\end{array}$ & $\begin{array}{c}-0.000299 \\
(0.000471)\end{array}$ & $\begin{array}{c}0.000193 \\
(0.000764)\end{array}$ & $\begin{array}{c}-0.00116^{*} \\
(0.000705)\end{array}$ \\
\hline AGE3 & $\begin{array}{r}-0.0000313 \\
(0.000579)\end{array}$ & $\begin{array}{c}0.000254 \\
(0.00144)\end{array}$ & $\begin{array}{r}-0.000195 \\
(0.00112)\end{array}$ & $\begin{array}{c}-0.000791 \\
(0.000761)\end{array}$ & $\begin{array}{c}0.000338 \\
(0.00123)\end{array}$ & $\begin{array}{c}-0.00282^{* *} \\
(0.00118)\end{array}$ \\
\hline AGE4 & $\begin{array}{c}-0.000204 \\
(0.000830)\end{array}$ & $\begin{array}{c}0.00228 \\
(0.00228)\end{array}$ & $\begin{array}{c}0.000208 \\
(0.00175)\end{array}$ & $\begin{array}{r}-0.00158 \\
(0.00103)\end{array}$ & $\begin{array}{r}0.000546 \\
(0.00169)\end{array}$ & $\begin{array}{c}-0.00682^{* * *} \\
(0.00168)\end{array}$ \\
\hline AGE5 & $\begin{array}{c}0.000171 \\
(0.00128)\end{array}$ & $\begin{array}{c}0.00149 \\
(0.00309)\end{array}$ & $\begin{array}{r}-0.000140 \\
(0.00259)\end{array}$ & $\begin{array}{r}-0.00224^{*} \\
(0.00136)\end{array}$ & $\begin{array}{c}-0.0000502 \\
(0.00237)\end{array}$ & $\begin{array}{c}-0.0101^{* * *} \\
(0.00232)\end{array}$ \\
\hline AGE6 & $\begin{array}{l}0.0000717 \\
(0.00171)\end{array}$ & $\begin{array}{c}0.00366 \\
(0.00464)\end{array}$ & $\begin{array}{r}-0.00194 \\
(0.00371)\end{array}$ & $\begin{array}{r}-0.00245 \\
(0.00177)\end{array}$ & $\begin{array}{r}-0.000169 \\
(0.00317)\end{array}$ & $\begin{array}{c}-0.0135^{* * *} \\
(0.00325)\end{array}$ \\
\hline INTERunempl & $\begin{array}{l}0.0157^{* * *} \\
(0.00259)\end{array}$ & $\begin{array}{l}0.0662^{* * *} \\
(0.0118)\end{array}$ & $\begin{array}{c}0.106^{* * *} \\
(0.00684)\end{array}$ & $\begin{array}{l}0.0222^{* * *} \\
(0.00277)\end{array}$ & $\begin{array}{l}0.0669^{* * *} \\
(0.00894)\end{array}$ & $\begin{array}{l}0.0968^{* * *} \\
(0.00608)\end{array}$ \\
\hline INTERservice & & & & $\begin{array}{c}0.00197^{* *} \\
(0.000909)\end{array}$ & $\begin{array}{c}0.000534 \\
(0.00199)\end{array}$ & $\begin{array}{l}0.0479^{* * *} \\
(0.00223)\end{array}$ \\
\hline INTERoth $^{1}$ & $\begin{array}{r}-0.000796 \\
(0.00103)\end{array}$ & $\begin{array}{c}0.0113 \\
(0.00700)\end{array}$ & $\begin{array}{c}0.0197^{* * *} \\
(0.00478)\end{array}$ & $\begin{array}{r}0.000657 \\
(0.00155)\end{array}$ & $\begin{array}{c}0.00230 \\
(0.00220)\end{array}$ & $\begin{array}{c}0.0323^{* * *} \\
(0.00506)\end{array}$ \\
\hline PARTTIME & $\begin{array}{c}0.00115 \\
(0.00110)\end{array}$ & $\begin{array}{c}0.00343 \\
(0.00314)\end{array}$ & $\begin{array}{c}0.00284 \\
(0.00260)\end{array}$ & $\begin{array}{c}0.00173 \\
(0.00269)\end{array}$ & $\begin{array}{r}-0.00428 \\
(0.00575)\end{array}$ & $\begin{array}{l}0.0145^{* * *} \\
(0.00484)\end{array}$ \\
\hline \#INTER & $\begin{array}{l}0.00485^{* * *} \\
(0.000993)\end{array}$ & $\begin{array}{l}0.0111^{* * *} \\
(0.00320)\end{array}$ & $\begin{array}{l}0.0212^{* * *} \\
(0.00229)\end{array}$ & $\begin{array}{l}0.00383^{* * *} \\
(0.000849)\end{array}$ & $\begin{array}{l}0.0113^{* * *} \\
(0.00186)\end{array}$ & $\begin{array}{c}0.0152^{* * *} \\
(0.00169)\end{array}$ \\
\hline \#PAST JOBS & $\begin{array}{c}-0.00203^{* * *} \\
(0.000411) \\
\end{array}$ & $\begin{array}{c}-0.00963^{* * *} \\
(0.00121)\end{array}$ & $\begin{array}{c}-0.0199^{* * *} \\
(0.00118) \\
\end{array}$ & $\begin{array}{c}-0.00241^{* * *} \\
(0.000323) \\
\end{array}$ & $\begin{array}{r}-0.0054^{* * *} \\
(0.000770) \\
\end{array}$ & $\begin{array}{r}-0.0125^{* * *} \\
(0.000785) \\
\end{array}$ \\
\hline$N$ & & 273207 & & & 276443 & \\
\hline
\end{tabular}

1 Summarizes interruptions due to service and other in female sample

Standard errors in parentheses ${ }^{*} p<0.10,{ }^{* *} p<0.05,{ }^{* * *} p<0.01$; Source: ALWA, own calculations 
Table 9 - Spell Fixed Effects Estimation (Number of Subordinates)

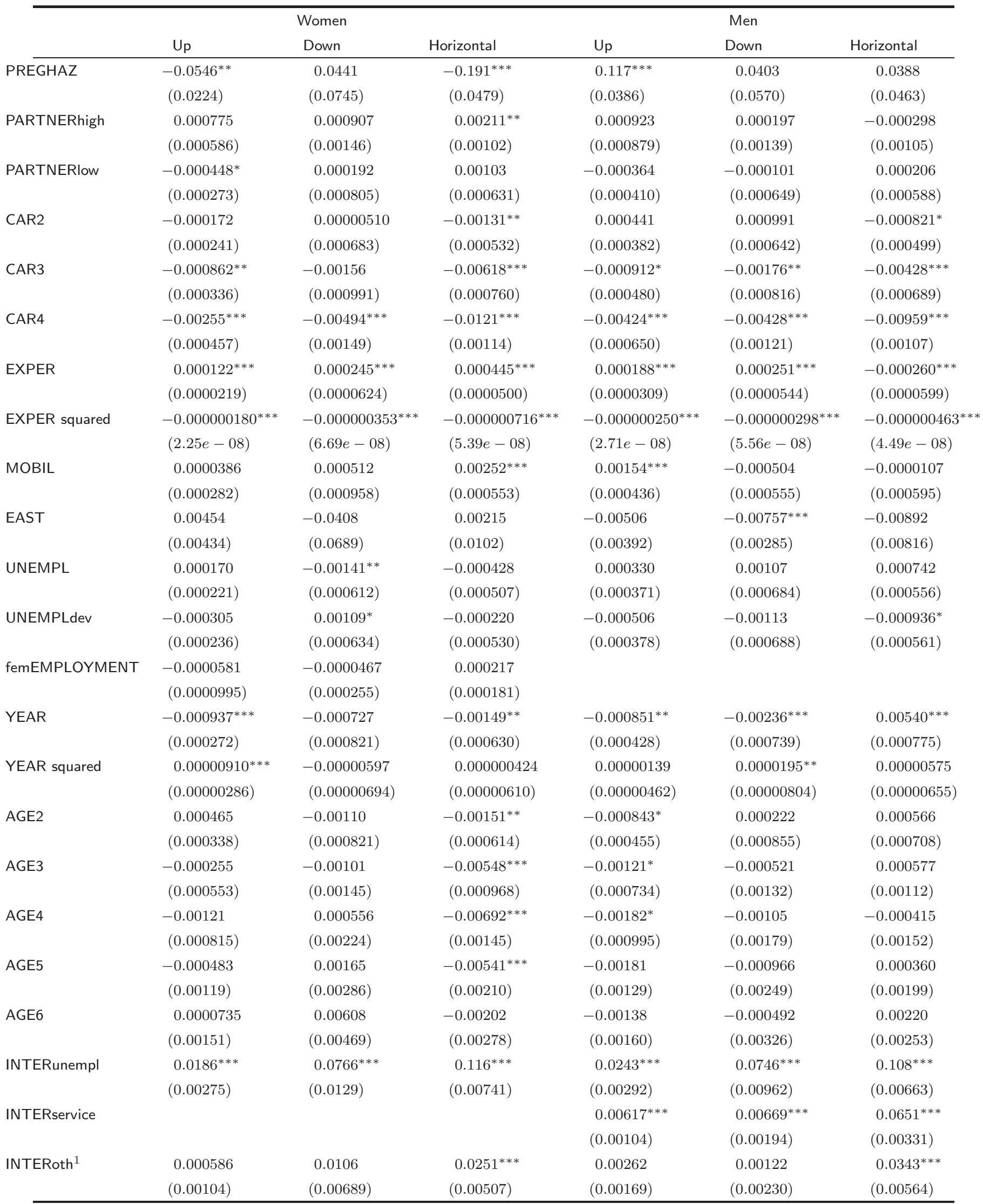




$N \longrightarrow 273207 \quad 276443$

1 Summarizes interruptions due to service and other in female sample

Standard errors in parentheses ${ }^{*} p<0.10,{ }^{* *} p<0.05,{ }^{* * *} p<0.01$; Source: ALWA, own calculations 